\title{
Национальные школы XX века - социокультурные и профессиональные парадигмы формирования архитектуры столиц. Центральноазиатский контекст
}

\author{
Е.Г.Малиновская, художественная галерея «ARK», Алматы, Казахстан
}

0бзор проектно-строительной ситуации формирования столиц Центральной Азии довольно специфичен по сравнению с зарубежной практикой ${ }^{1}$ в связи с особенностями местной климатической и историко-культурной ситуации. Столицами Советского Востока, начиная с 1920-х годов, становились уже существовавшие города, нередко древние, что неминуемо сказалось на концептуальной основе деятельности архитекторов Центра², задавая творческий вектор на использование традиций. Демократическая доктрина тех лет - культурное наследие - также ориентировала на его переосмысление, вплоть до самых ортодоксальных новаторов. Как в то время, так и в неменьшей степени позднее, в 1970-е годы приезжих архитекторов волновали и собственно творческие задачи - перспектива расширения арсенала современных приёмов и средств, использование инонациональных образцов местной традиционной культуры. В сходной историко-культурной и профессиональной ситуации по сравнению с деятельностью архитекторов авангарда оказался один из выдающихся мастеров модернизма А.С. Косинский, в проектах по реконструкции Ташкента по существу реализовавший методологические установки советской новаторской архитектуры. Большая часть его проектов-новаций, оставшихся нереализованными, подобно работам 1920-х годов, базировалась на футуристических идеях, как их воспринимали современники, но чью жизнеспособность доказала мировая практика конца XX века.

Ключевые слова: Центральная Азия, новые столицы, советский авангард, конкурсы соцрасселения, проекты-утопии, «оседание кочевников», концепция места и времени А.С. Косинского.

\section{Young National Schools of the XX Century - Socio-Cultural and Professional Paradigms for Forming the Capital Architecture. Central Asian context}

\section{E.G.Malinovskaya, ARK Art Gallery, Almaty, Kazakhstan}

The review of the design and construction situation of formation of Central Asian capitals is rather specific in comparison with foreign practice due to the peculiarities of local climatic, historical, and cultural situations. The capitals of the Soviet East, starting from the 1920s, were already existing cities, often ancient, which inevitably affected the conceptual basis of the architects of the Center, setting the creative vector to use traditions. The democratic doctrine of those years - cultural heritage also focused on its rethinking, up to the most orthodox innovators. Both at that time and to a lesser extent later, in the 1970s, visiting architects were also concerned with creative tasks - the prospect of expanding the arsenal of modern techniques and means, the use of foreign examples of local traditional culture. In a similar historical, cultural, and professional situation as compared to the activities of the architects of the avant-garde was one of the outstanding masters of modernism, A.S. Kosinsky, who essentially implemented the methodological guidelines of Soviet innovative architecture in projects for the reconstruction of Tashkent. Most of his project innovations, which remained unrealized, like the works of the 1920s, were based on futuristic ideas, as they were perceived by contemporaries, but whose viability was proved by the world practice of the late twentieth century.

Keywords: Central Asia, new capitals, Soviet avant-garde, social settlement contests, utopia projects, "settling of nomads", A.S. Kosinsky's concept of place and time.

Там, где нет утопии, открывающей новые возможности, настоящее затхло, бесплодно... Без утопий культура быстро окажется обращённой в прошлое. Настоящее же живёт полной жизнью только при наличии связи прошлого с будущим.

Пауль Тиллих [1, с. 15]

\section{Игры в прозрения или путешествие в неведомое}

Архитектурные хроники начала XX века демонстрируют всё возраставший интерес к культуре Востока. В использовании его наследия, как и ранее, имели место, хотя и незначительно, ретроспективные тенденции в декоре особняков, городской ратуши Стокгольма, павильонов выставок в Гётеборге и Париже. Конструктивные элементы азиатской архитектуры - «игрушечные» купола, минареты, - выступая

${ }^{1}$ Статья является продолжением материала, опубликованного в № 2 журнала «Academia. Архитектура и строительство» за 2020.

${ }^{2}$ Архитекторы Центра - принятое в те годы обозначение для командированных в регион. 
в большей мере символом региональных традиций, украсили и советские общественные, промышленные объекты: здания Водхоза, Центрального комитета компартии (арх. Г. Сваричевский) и института ирригации (арх. А. Горшенян) в Ташкенте; плотину Бегаватского канала', павильоны Первой Всероссийской кустарно-промышленной выставки (Москва, 1923) ${ }^{4}$ (рис. 1)

В отличие от построек В.Н. Львова, применившего характерные азиатские детали (колонны, айваны, купола) в зданиях Сельхозбанка, Кожсиндиката (1926) в Кзыл-Орде, новой казахстанской столице тех лет, обнаружил себя, пожалуй, первый пример кардинально иного, новаторского подхода к проблеме. Клуб и серия домов комплекса «Новый город» (1925) были построены согласно типологии регионального жилья. Их автор С. Андриевский, студент ВХУТЕМАСа, следовал авангардистским принципам в выборе источника и характера использования традиций. Это были азиатские архитектур-

${ }^{3}$ С критикой названных сооружений выступили сами профессионалы [2].

${ }^{4}$ Подобные стилизаторские приёмы использовались в павильонах республик Востока: Туркестана (арх. Ф. Шехтель) [3], а также Киргизии, Татарии, Армении (арх. Н. Буниатов), Азербайджана (арх. Я. Сырыщев). Исключение - павильон Крыма (арх. М. Гинзбург), прообразом которого стало народное жилище.

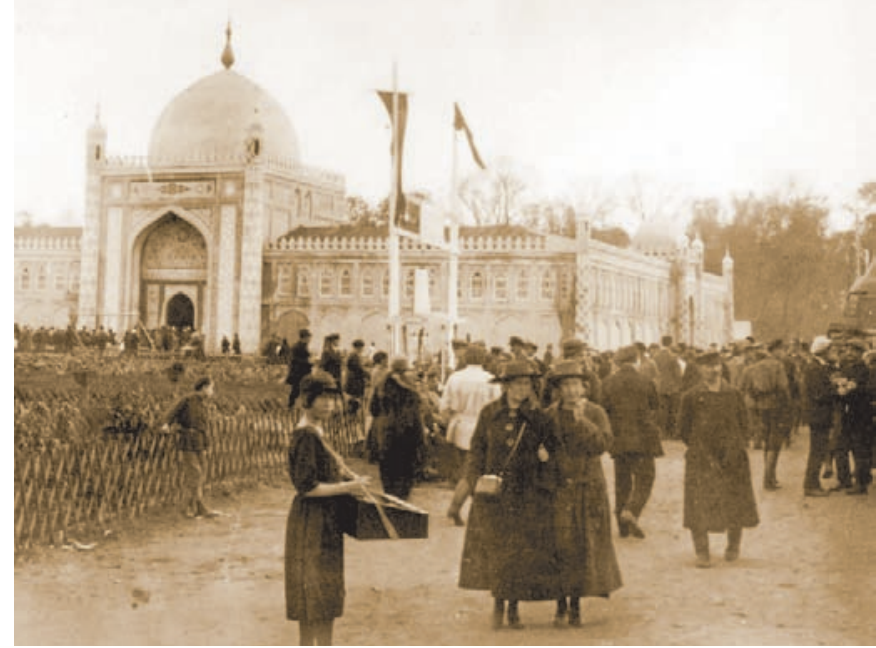

a)

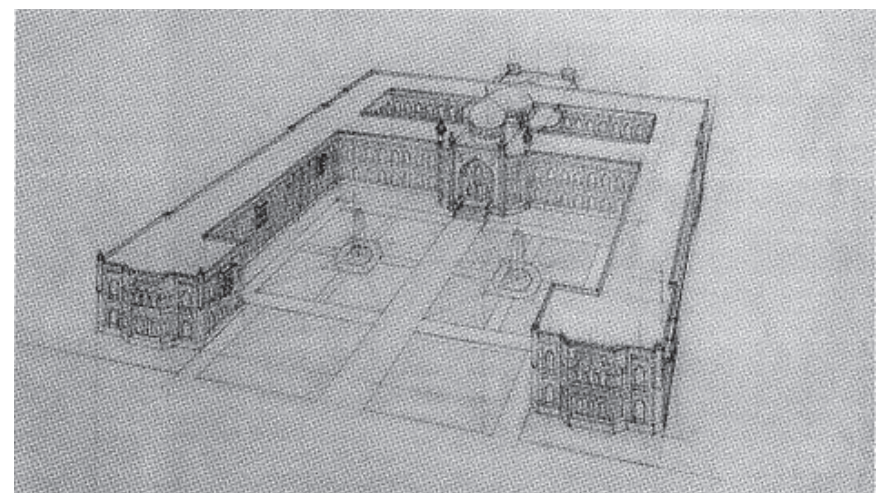

б)

Рис. 1. Москва. Первая Всероссийская кустарно-промышленная выставка. Павильон Туркестана. Архитектор Ф. Шехтель. 1923 год: а) панорама здания; б) аксонометрия; в) рабочий рисунок декора центрального входа но-планировочные приёмы, спасающие от зноя: материалы (сырцовый кирпич), «глухие» наружные стены, а по периметру внутреннего двора проходили галереи (айваны). Акцентируя здание клуба в прилегающей застройке, автор ввёл современно решённые элементы - большие окна на фасадах, завершённых озеленёнными перголами, но на традиционных плоских глинобитных кровлях. Сходные визуально принципы синтеза новаторства и традиций, но образно-технологически более близкие современности, использованы в проектах Физического института (арх. А. и Л. Веснины, Ташкент, 1927) и театра (арх. Г. Вегман, Самарканд, 1927) (рис. 2).

Выдвинувшаяся на первый план архитектура авангарда продемонстрировала новые по функции сооружения в молодых столицах Советского Востока. Конструктивистские объекты появились в Баку и его окрестностях: рабочие клубы (арх. братья Веснины, 1928-1932), спорткомплекс «Динамо» (арх. М. Гусман, К. Сенчихин, 1928), фабрика-кухня (арх. С. Дадашев, М. Усейнов, 1930), Дворец печати (арх. С. Пэн, 1928). В Ташкенте построили Дом правительства (арх. С. Полупанов, 1931), фабрику-кухню (арх. Чернявский, 1930), Дом-коммуну (арх. С. Полупанов, 1931) (рис. 3).

Их авторы стали последователями М. Гинзбурга, задавшего тон в решении типологии и стилистики советских администра-

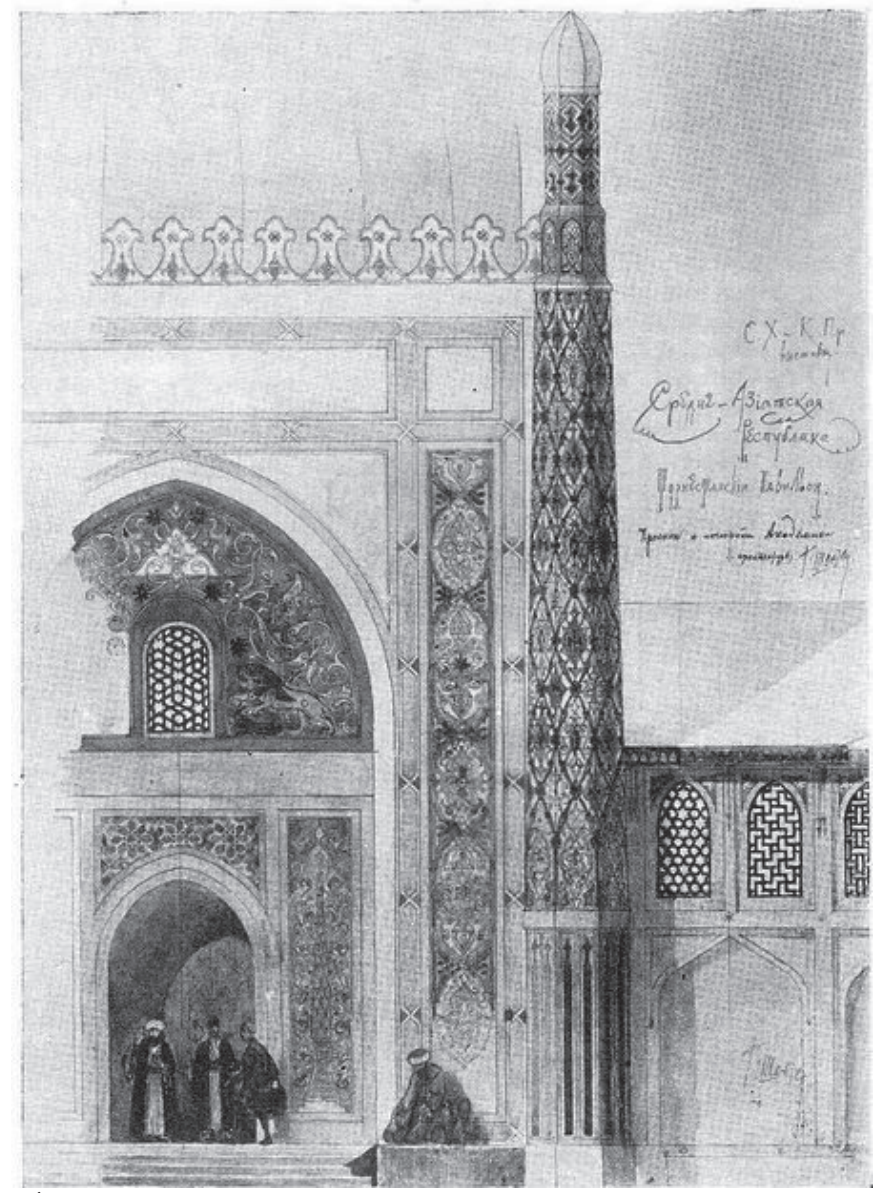

B) 


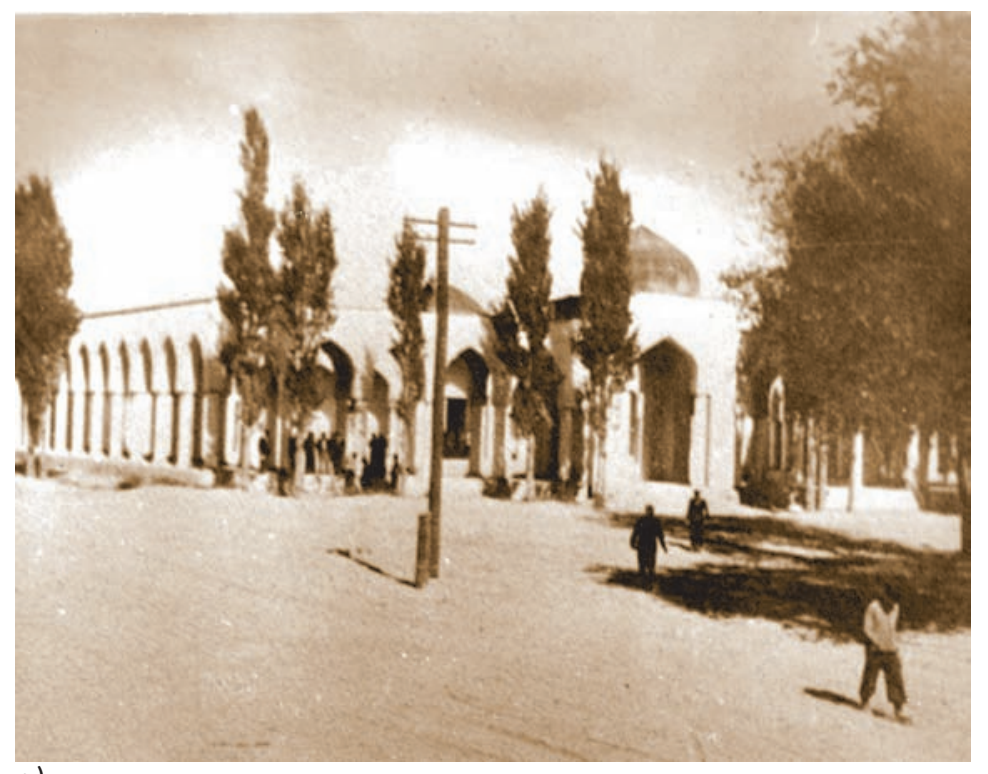

a)

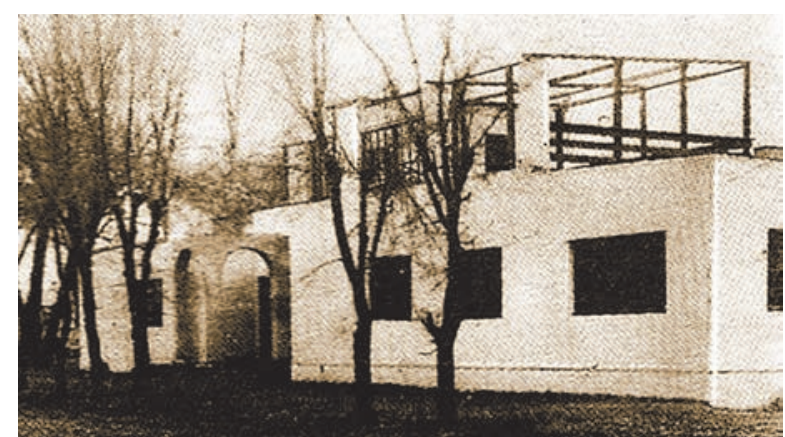

б)

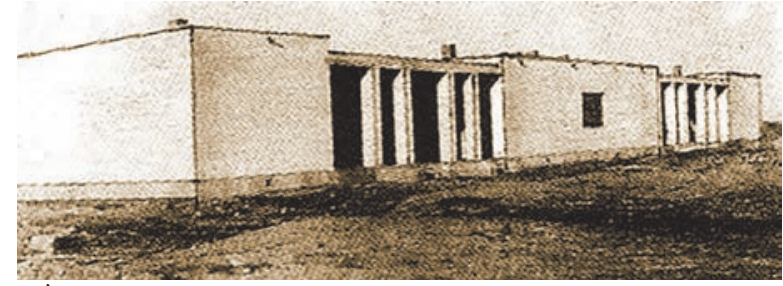

B)

Рис. 2. Кзыл-Орда (1925-1927 годы): а) здание Сельхозбанка, общий вид. Архитектор В.Н. Львов. 1926 год; б) рабочий клуб, перспектива. Архитектор С. Андриевский. 1925 год; в) фрагмент жилой застройки «Нового города», перспектива. Архитектор С. Андриевский. 1925 год

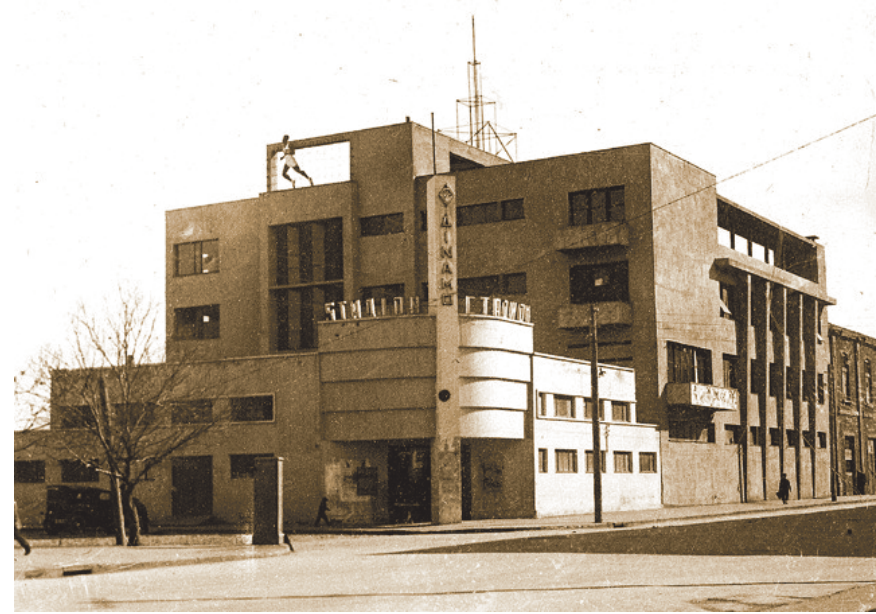

a)

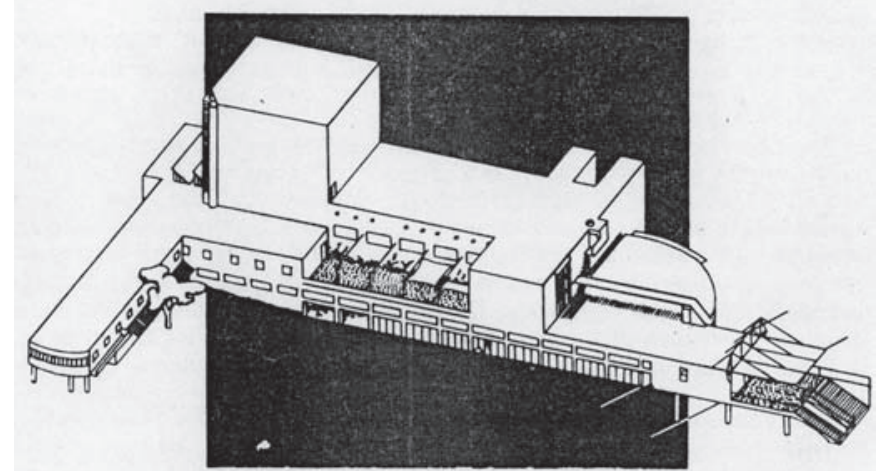

б)

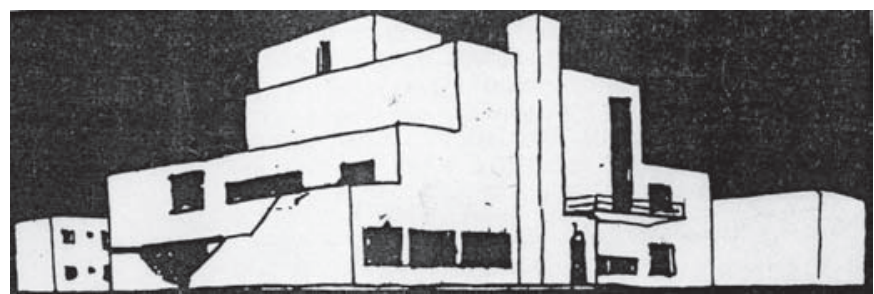

B)

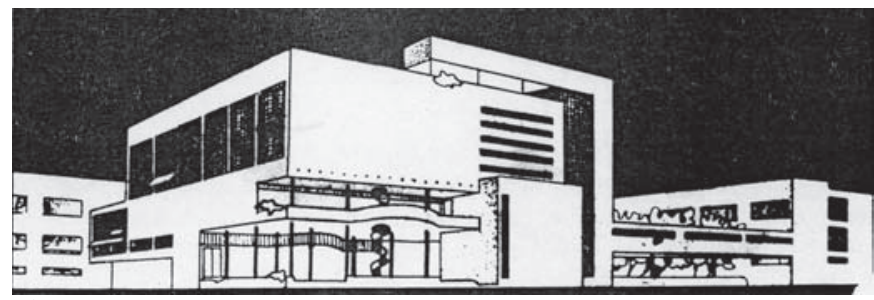

2)

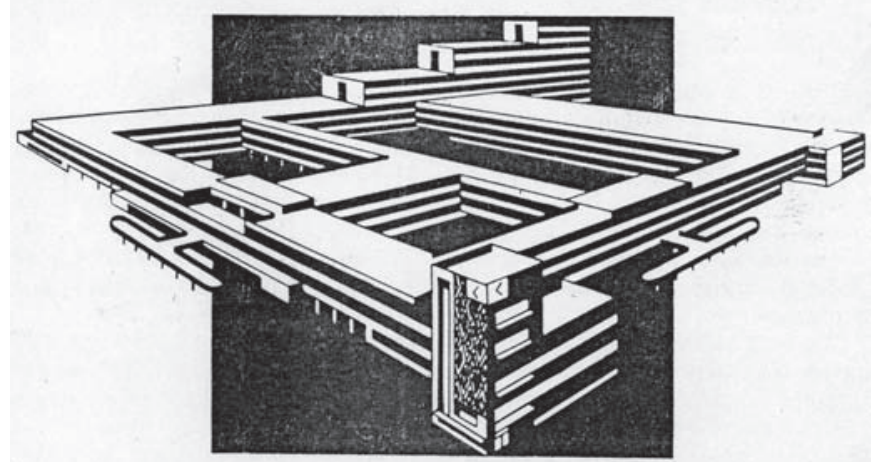

d)

Рис. 3. Сооружения конструктивизма в столицах Советского Востока: а) Баку. Спорткомплекс «Динамо». Архитекторы М. Гусман, К. Сенчихин. 1930 год; б) Самарканд. Проект театра, перспектива. Архитектор Г. Вегман. 1927 год; в) Ташкент. Проект Физического института, перспектива. Архитекторы А. и Л. Веснины. 1927 год; г) Алма-Ата. Проект здания Дома правительства КА ССР. Перспектива главного фасада. Архитектор М. Гинзбург. 1928 год; д) Самарканд. Проект Дома Правительства Узбекской ССР. Перспектива. Архитектор А. Щусев. 1930 год 
тивных сооружений, представив проект Дома правительства в Алма-Ате (1927). Лидер конструктивизма программно отрицал - «туристская экзотика» - эксперименты с монументальной архитектурой «улугбеков». Анализ комплексов Бухары убедил его в возможности освоения наследия на уровне функционалистских аналогий с народной архитектурой - «жилище бедного мусульманина» [3, с. 39-49]. М.Я. Гинзбург, здраво оценив приёмы климатической адаптации, конструктивно-образную и планировочную логику наследия, закрепил свою концепцию в алматинском проекте, которая, однако, не преодолела рамок конструктивистской стилистики [4].

В деятельности новаторских архитекторов, помимо осуществлённых проектов, даже более значима уникальная конкурсная работа футуристического характера. Предваряя анализ этого,

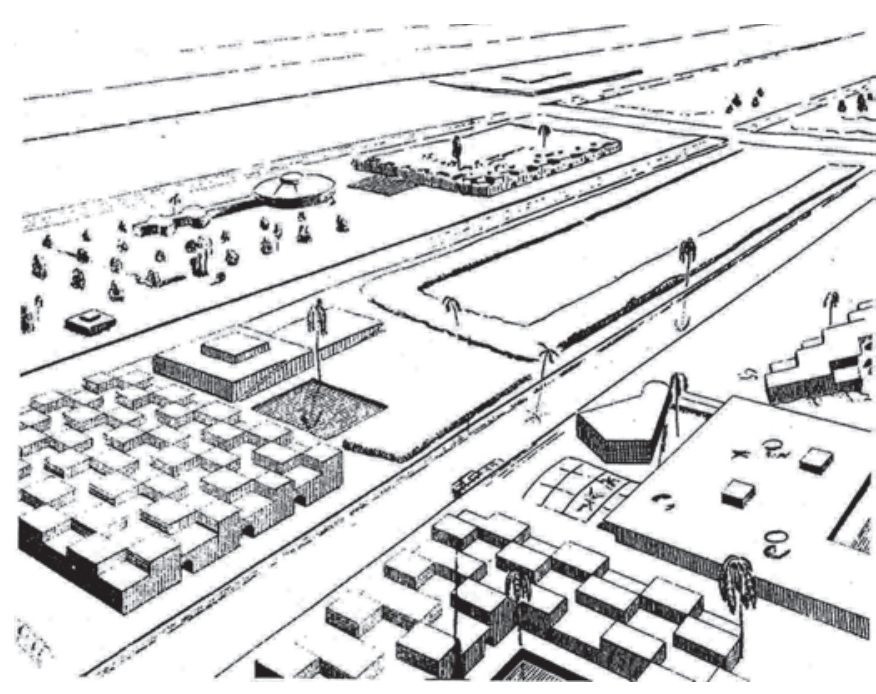

Рис. 4. Новый Чарджоу. Проект застройки. Перспектива. Бригада АРУ, архитекторы В. Лавров, В. Попов. 1933 год

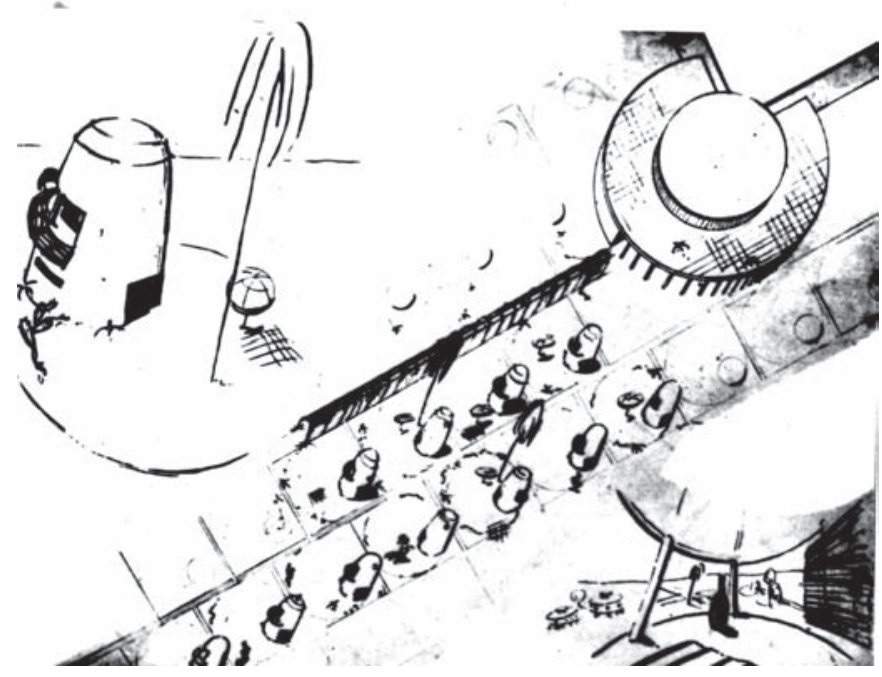

Puс. 5. Соцгород в Средней Азии. Проект застройки. Перспектива. Архитекторы В. Калмыков, Л. Гришпун. 1931 год долгое время неисследованного проектного материала, который затерялся в периодических изданиях, архивах, следует осознать причины и суть данного явления. Революционный романтизм 1920-х годов в доктрине нового жизнеустройства актуализировал социально-утопические идеи всех времён и народов. И чтобы понять - во имя чего - обратимся к архитектурным утопиям XX века, имеющим непосредственное отношение и кпослереволюционной проектно-строительной практике в Центральной Азии.

Следует определиться как с самим понятием, так и термином. «Utopia» означает «чего нет нигде». История утопий - это стремление представить себе другие варианты будущего 5 . Они противостоят власти и оспаривают ею навязываемую реальность, порождая надежду. Проекты-утопии - идеал, выдвигаемый ценностями, которые иллюзорны, но подразумевают конкретное общество. Как правило, они несут в себе критику или скепсис по отношению к настоящему, но предсказанное будущее, с его идеальным обезличенным бытием, вместе с тем выглядит порой пугающе. Утопии - это история упорной надежды обретения лучшего общества через архитектурную модель новой среды обитания - некоего города Счастья.

Проекты-фантазии, постулируемые советским авангардом при поддержке деятелей партии и государства, социологов, экономистов, участников масштабных дискуссий о социалистическом расселении, прокладывали вектор в неведомое «послезавтра». Особенно отечественное зодчество оригинально и смело проявило себя, увлечённо строя прогнозы «жизнедеятельности народов Востока», что мало исследовано. Подобные идеи, опираясь на традиции, стали антитезой обезличенным проектам образцовых соцгородов. Не связанные с факторами места, они демонстрировали только новаторство, то есть профессиональный контекст.

В работах советских архитекторов для столиц национальных республик присутствовал, бесспорно, утопический по размаху реконструкции, но всё же конкретный образ - Азиатского региона, - связанный с местной культурой, природой [5]. Это характеризовало проекты всех участников конкурса для

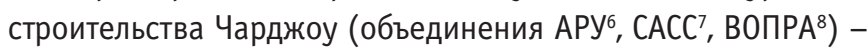
новой столицы Туркмении [6]. Создавались не столько проекты города, зданий, но по существу новая модель жизнестроения нации [7, с. 123]. Историко-культурный опыт Азии стал импульсом для творческого поиска в приёмах градообразования, озеленения, обводнения: сады-дворики, солярии на кровлях, многочисленные каналы, бассейны, фонтаны. Играли роль материалы зданий, их типология, взятые из оседлого и кочевого жилья. Конструктивно совершенные купольные постройки, характерная особенность зодчества региона, служили градостроительными доминантами проектов [8, с. 15] (рис. 4, 5).

${ }^{5}$ На материале новых зарубежных столиц отмечалось, что при их строительстве всегда шёл процесс прогнозирования, однако утопии - совершенно иное явление.

${ }^{6}$ Объединение архитекторов-урбанистов.

${ }^{7}$ Сектор архитекторов социалистического строительства.

${ }^{8}$ Всероссийское общество пролетарских архитекторов 
Хаирхан, автор одной из интереснейших архитектурных фантазий конкурса по соцрасселению, выдвинул идею «многоэтажного» дома-«города» в Азии ${ }^{9}$. Развёрнутая по горизонтали структура из системы улиц-«этажей» представала как индустриальная фантазия: самодвижущиеся тротуары, искусственный микроклимат с тепло- и хладоцентралями, противопыльными устройствами, увлажнением земли пульверизаторами.

Прогнозируя идеальный город Востока, Хаирхан предостерегал от радикальных преобразований: «для эмоциональной конституции этих масс совершающаяся перемена жизни катастрофический прыжок в невиданный и невообразимый мир» [9]. Возражал против «физического типа построек, копирующих север, вредных для здоровья», европейского квартала, настаивая на плотной асимметричной застройке по типу махалля (азиатский жилой кластер семейного клана) [10, c. 45]. Архитектор предлагал традиционные средства климатической адаптации - систему ирригации, затенённые циновками или небольшими куполами улочки коридорного типа (чорсу): «для нас разумная схема не опорочена одним лишь тем, что до неё добрались предки вековым опытом» [11, с. 62].

9 Чудом сохранившись после советских «чисток» в библиотеках, теория Хаирхана введена в научный оборот в диссертации, в публикациях автора статьи.
Ценность подобных установок особо ощутима при сравнении проектов Хаирхана и города-сада Голодностепска (автор Г.К. Ризенкампф, 1918), одной из первых азиатских столиц, где разделили «туземцев» и «европейцев» ${ }^{10,11}$. Кон-

${ }^{10}$ РГИА. Ф.432. Оп. 1. Ед. хр. 768.

${ }^{11}$ Материал впервые был введён в научный оборот [7, с. 122]. Город и серию населённых пунктов вдоль каналов проектировали в связи с воплощением грандиозного проекта орошения Голодной степи - ИРТУРа (Ирригация Туркестана). В работе участвовал и Ф.О. Шехтель, который работал в Туркестане, что объясняет «восточность» его поздних работ.

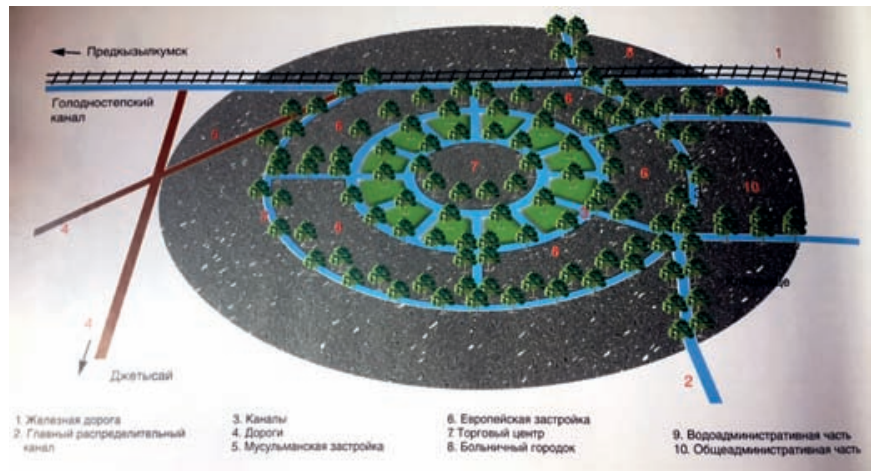

Рис. 6. Голодностепск. Проект ИРТУР, архитектор Г.К. Ризенкампф. 1918 год
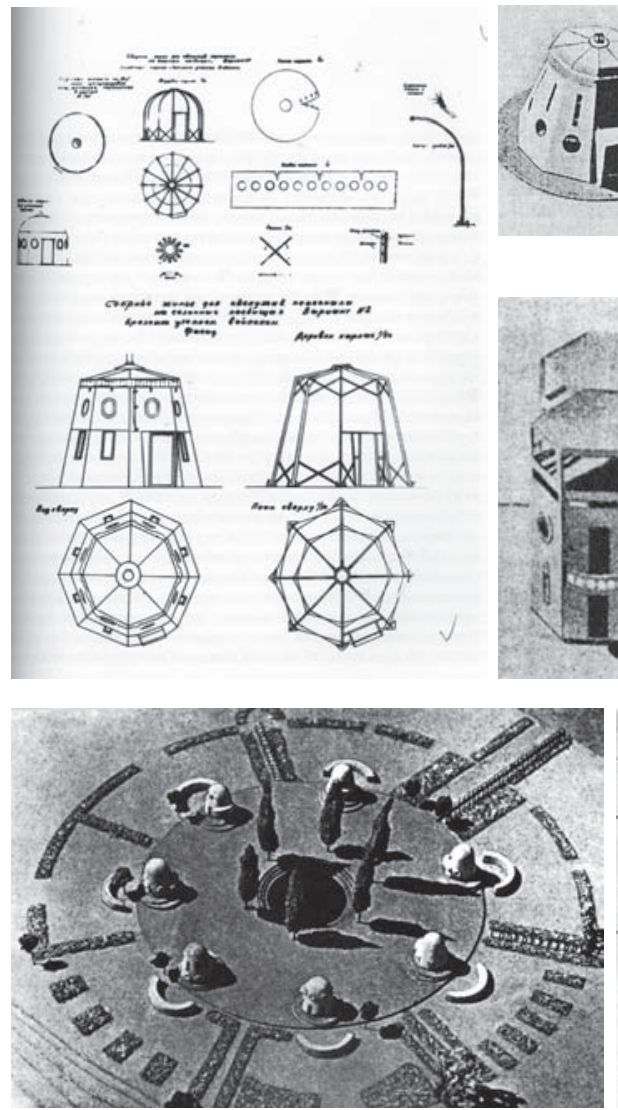

a)
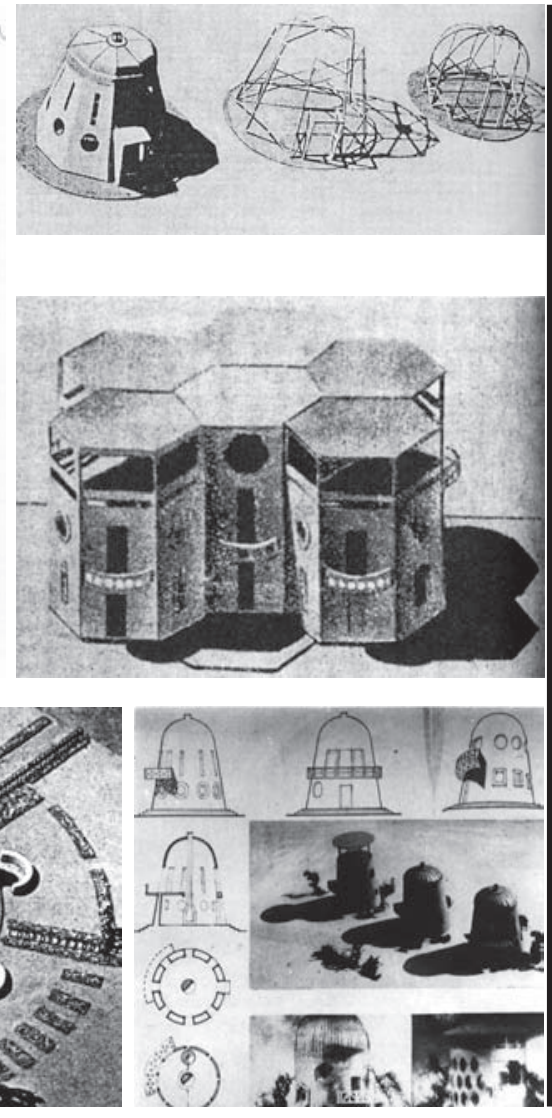

б)

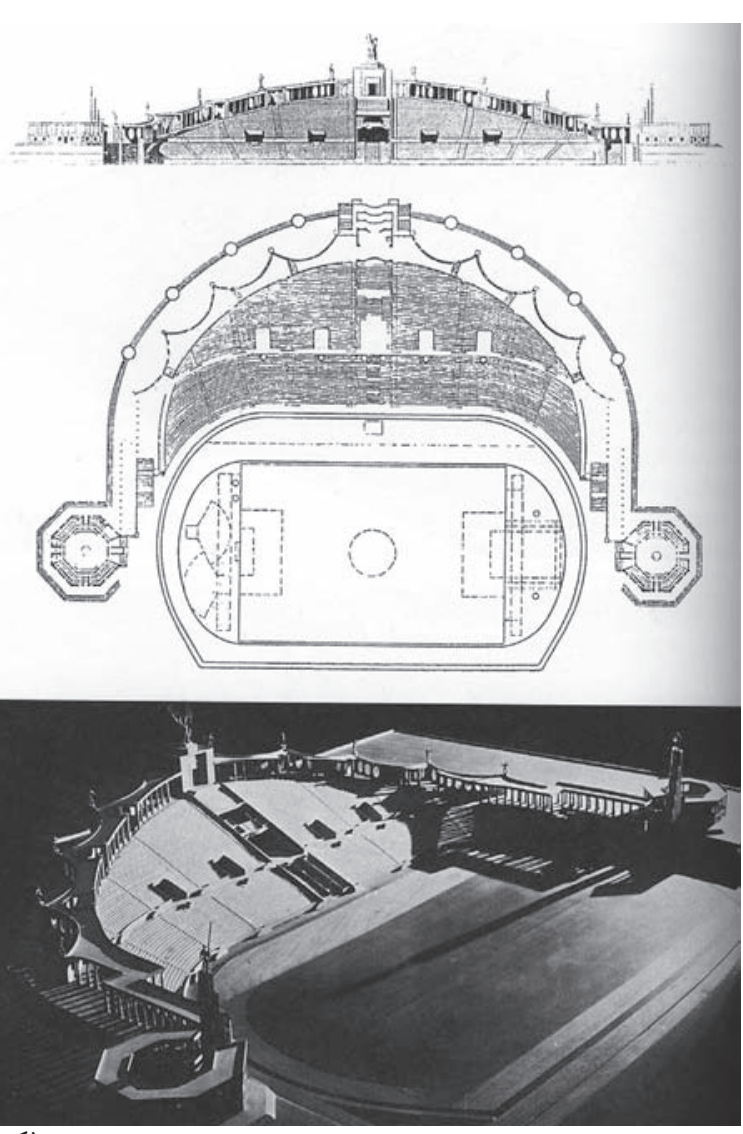

)

Рис. 7. Проекты для «оседающих кочевников» (а): макеты, общий вид, планы, разрезы зданий, генпланы. Архитектор В. Калмыков. 1933 год; б) Физкультурный комбинат. Проект: амфитеатр трибун, план, перспектива, фасад со стороны футбольного поля. Архитектор В. Калмыков. 1934 год 
траст разительный (рис. 6). Архитектурная пресса отмечала перспективы изучения конкурсной работы по проектированию соцгородов «для пустынных районов Средней Азии или оседающих кочевников, где требовалось учесть устоявшиеся формы быта, привычные зрительные восприятия и местные материалы вместе с распространёнными методами конструирования здания» [12].

Другой участник конкурса, выходец из Ташкента, В. Калмыков проявил себя необыкновенно талантливым интерпретатором местной строительной культуры и в дальнейшем ${ }^{12}$. Архитектор предлагал - «в преодоление трафаретности» новой архитектуры - использовать сырцовую кладку стационарного азиатского жилья, совмещая её с пейзажным принципом планировки кочевья в круговых, секторальных схемах. Для «оседающих кочевников»он разработал проекты стационарных и сезонных переносных коттеджей, многогранных в плане с полусферическим завершением в двух или трёх уровнях - постмодернистскую фантазию на тему юрты. Отработанные в этих сериях приёмы - лёгкость монтажа, типизацию элементов В. Калмыков использовал в проектах многоэтажных домов, санаториев для различных рельефов и климатических зон в регионе (полупустыни, предгорья) и Физкультурного комбината (Ташкент) [14] (рис. 7).

Аналогичную быструю сборку из типовых деталей применили А. Бунин, М. Круглова в модернистских по стилистике проектах жилья для «безлесных районов». Традиционные приёмы саманной кладки авторы сочетали с новаторскими большие выпуклые окна, современные террасы, затенявшие жилые ячейки в двух уровня, построенные из фабричных плит [15, с. 22] (рис. 8).

Помимо разработок приезжих архитекторов-новаторов существовал и своеобразный, не пересекающийся с ними, «параллельный мир» - деятельность прогрессивно мыслящих центральноазиатских учёных и местных проектировщиков. С начала XX века Л.Н. Воронин, Б.Н. Засыпкин,

12 В. Калмыков, один из наиболее одарённых учеников Н. Ладовского (ВХУТЕМАС), проделал масштабную научно-практического характера работу: множество проектов, статьи, диссертация, документальная кинолента (1932) [13].

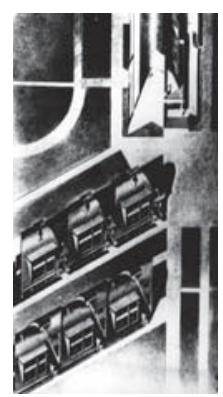

a)

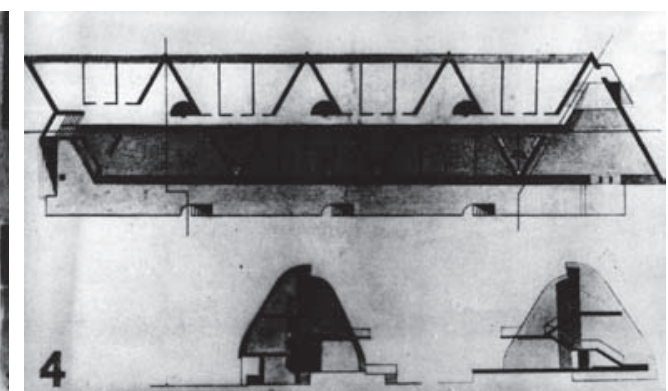

б)
Pис. 8. Джезказган. Проект дома-ячейки для «безлесных районов». А. Бунин, М. Круглова 1929 год: а) общий вид; б) разрез, аксонометрия
С.Н. Полупанов, Г.М. Сваричевский активно демонстрировали в теории и проектах перспективы и возможность внедрения в практику технико-конструктивных, градостроительных традиций региона. В советское время идеологи культуры стали отвергать историческое зодчество, относя его к объектам мусульманского культа. Отстаивая свою позицию, местные учёные писали об «архитектурном иконоборчестве», «ритуальной подоплёке», «архитектурном жупеле» ${ }^{13}$. Вульгарно-социологический подход тех лет, в конечном итоге победивший в советской архитектуре, перечеркнул как их работу, так и новаторов.

Гражданский инженер Г.М. Сваричевский, знаток регионального зодчества, разработал проекты зданий купольного типа, начиная с Торгово-промышленного музея (1915) в виде эллиптического семиярусного объёма купола до земли, предвосхитив идеи И. Леонидова. Неосуществлённые проекты советского времени Г.М. Сваричевского предполагали строительство в новаторских конструкциях (ребристые железобетонные купола) и новых по функции сооружениях: Музей искусств (1920), конкурсные серии жилья «Скорострой» (1925), «Полушарие-30 и 31»- многоэтажные дома-коммуны [17, с. 650].

Проекты архитекторов Центра и региона не повторяли слепо историческое наследие. Установки новаторской архитектуры стали фильтром в отборе традиционных приёмов, стыкуя контексты культур: современной и исторической, профессиональной и народной, Запада и Востока. Города проектировались в связи с доминирующими концепциями соцрасселения - дезурбанизма или урбанизма, на котором настаивал Хаирхан: «индивидуалистическое жилье укрепляет род» [11, с. 62]. В структуре «этажей» идеального города Востока архитектор также реализовал другую популярную тогда планировочную схему - линейную.

Специфика проектов для Центральной Азии связана также с поиском новых форм жилья, исходя из возможностей авангардной архитектуры - конструктивно-планировочных экспериментов, материалов, образно-выразительных приёмов. Получившие реализацию во многих советских городах «круглые», «кольцеобразные» в плане, дома-«сферы», купольные сооружения великолепно отвечали и региональной эстетике [18] (рис. 9).

Вся эта широкомасштабная научно-практическая работа для республик Востока была отброшена, заклеймённая как утопическая, среди прочих нереализованных идей 1920-х годов. В Центральной Азии проекты не получили признания, ассоциируясь с отсталостью - «феодальное прошлое». В особенности строительство из регионального материала -

${ }^{13}$ Архивные документы, введённые впервые в научный оборот [7, с. 119], позволили сравнить эти установки с выводами Л.Я. Маньковской [16], сделанными в 1980-е годы на основе типологического анализа построек региона, доказавшими наличие единых конструктивно-формальных и декоративно-эстетических элементов, вопреки укоренившейся «культовой» их трактовке (см. ЦГА РУз. Ф.Р.-2242. 0п. 1. Ед. хр.79. Л. 1; Ф. 2406. 0п. 1. Ед. хр. 256. Оп. 1. Ед. хр. 256). 
сырца [19, с. 202] ${ }^{14}$. Декларативно утверждались перемены. Под давлением партноменклатуры приняли проекты типовых посёлков-резерваций. Процесс «оседания кочевников» в реалии оказался архитектурным геноцидом, сломом этнокультурных стереотипов номадов, закончившийся голодом [20].

«Игры» в прозрения о будущих социалистических городах завершились болезненным «пробуждением» под молохом тоталитаризма. Пришел конец иллюзиям. Вместо городов-садов на костях тысяч заключенных гигантского концлагеря, в который был превращён регион, появилась архитектура, не имевшая ничего общего с первоначальными замыслами [21, с. 132].

Однако то, что игнорировали политики, было определяющим для авторов проектов, которые отметили, что в Европе всё-таки отважились на эксперименты с кочевыми формами. В Москве даже противники «круглых домов» не возражали против их строительства в сельской местности. В. Калмыкову удалось воплотить свои идеи в дачных посёлках Подмосковья «Куртинки» и «Круглая роща» (1930) - более ста зданий [23, с. 31] $]^{15}$.

Зарубежный опыт имел опережающий по времени характер, заметим при этом, осуществлённых проектов. «Поворот архитектуры к Востоку» отметила западная печать [24]. Лидером в этой ориентальной волне стала юрта, тип сооружения, который ранее даже не считали собственно архитектурой. Бруно Таут, знаток архитектуры Востока, сказал, что кочевое жилище для него служит эталоном своеобразной эстетики, удобства и простоты интерьера, меблировки: встроенные шкафы, трансформирующиеся перегородки. Немецкий архитектор реализовал свои идеи в выставочном павильоне (Кёльн, 1914) и серии «Дом будущего» (1923), применив, как он писал, вместо дорогостоящей каменной кладки стену и призматический купол из цветного стекла или же черепичную кровлю до земли $[25, \text { с. 473 }]^{16}$.

Сенсационная, отметила европейская профессиональная пресса, вращающаяся постройка «Солнцеворот» рижских зодчих Лекюйе и Жабо (1924) ${ }^{17}$, жилой дом Карла Фигера (1926) реализовали преимущества - конструктивные, экономические, функциональные - кочевого прообраза [25, с. 474]. Особый акцент сделан на простоте сборки стандартных

${ }^{14}$ В Кзыл-Орде устроили судебный процесс, далее - тюрьма, БеломороБалтийский канал.

${ }^{15}$ В мемуарах князя С. Голицына сохранилось описание структуры такого дома, названного жильцами «Круглым», с трапециевидными в плане комнатами. Обогревался печью, расположенной в центре, с расходящимися по радиусам трубами; под потолком первого этажа и в полу второго имелись дверки-воздуховоды. Здание оказалось очень дешёвым - деревянный каркас с забутовкой глиной. Отметив его комфортность, С. Голицын связал необычность решения с характером революционной эпохи [22, с. 592].

${ }^{16}$ https://expressionism.academic.ru/613/Таут\%2С_Бруно.

${ }^{17}$ В недавнем материале о Г. Крутикове, разработчике оригинальнейшего проекта «Летающего города», отмечено: он признавал, что на его теорию движущейся формы оказала решающее влияние идея европейской виллы, поворачивающейся за солнцем, с которой познакомился в одном из журналов начала 1920-х годов, то есть, публикации Г. Вольфензона, которую автор статьи отыскала в периодических изданиях тех лет (источник: https:/ tatlin. ru/articles/gorod_budushhego_iz_proshlogo). современных заводских плит и экономичности строительства (более чем в два раза).

Конкурсные материалы тех лет не утратили своей актуальности, как показывает мировая практика, в частности проект Хаирхана. В течение сорока лет строился гигантский шестигранный в плане дом-«город» Аркозанти (арх. Паоло Солери, (ША), состоящий из трёхсот распластанных по горизонтали зданий, связанных в сложную структуру. Архитектор материализовал идею жизнеспособной футуристической экосистемы, замкнутой от жара пустынь [7, с. 123].

Интерес к традиции кочевых построек возник в мировой практике в 1980-е, а затем еще более широко в 2000-е годы ${ }^{18}$. В связи с энергетическим кризисом, поиском новых форм жилья вновь появились вращающиеся особняки, здания с кровлей до земли, дома-«сфероиды» и многое другое на разных широтах - от Скандинавии до Марокко. Аргументы в их пользу те же, что и в дебатах 1920-х годов: рациональность монтажа, микроклимат, экономичность, простота обогрева [26]. А решения до невероятности похожи на «кибитки» В. Калмыкова, К. Фигера и Б. Таута (рис. 12).

Перифраза азиатских купольных построек (арх. Герли и Борсани), как и проект громадного дома-купола (Dome House, 1948) Паоло Солери, - по существу реализация идей Г.М. Сваричевского [27] ${ }^{19}$. Целесообразность, экономичность строительства из модернизированного кирпича-сырца была апробирована на практике. Кроме Фатхи, внедрившем местный опыт в египетском поселении Новая Курна (1948), из терраблоков строят виллы, пятизвёздочные отели, жилые комплексы в Австралии, Аргентине, Колумбии, США. Швейцарская студия «Ветш Арчитектур» (Vetsch Architektur) проектирует элитные дома с 1974 года. Во Франции проводятся выставки, конкурсы «глиняной

18 Успешны фирмы по строительству аутентичных юрт или же современных стационарных, сезонных жилищ для туристов, молодожёнов, дачных посёлков (источники: www.yurt.bg; http://www.magazindomov.ru/2011/05/15/ kruglaya-villa-v-yaponii).

${ }^{19}$ https://www.houzz.ru/ideabooks/63157968/list/zhity-v-kokone-10kruglyh-domov-iz-raznyh-stran.

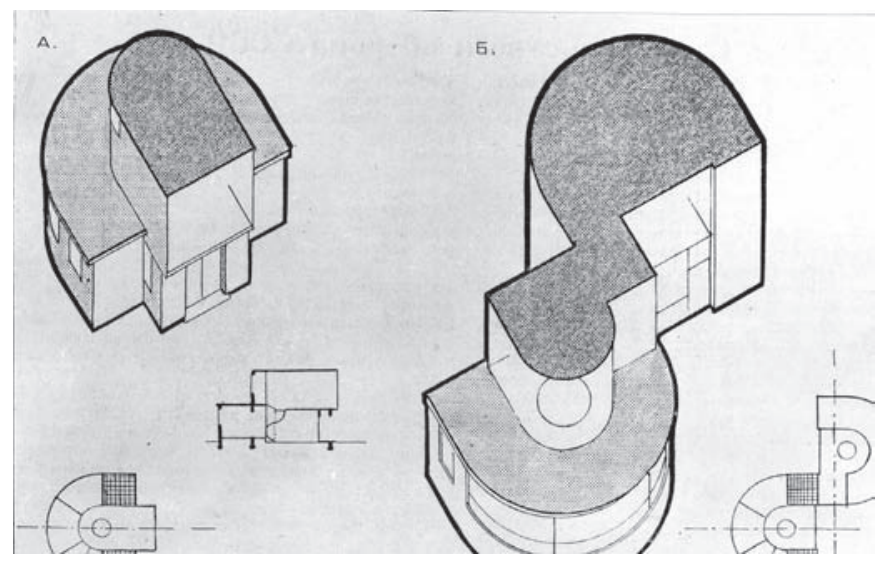

Pис. 9. Полукруглый в плане жилой дом. Проект: общий вид, планы, разрез. Архитектор Г. Крутиков. 1927 год 

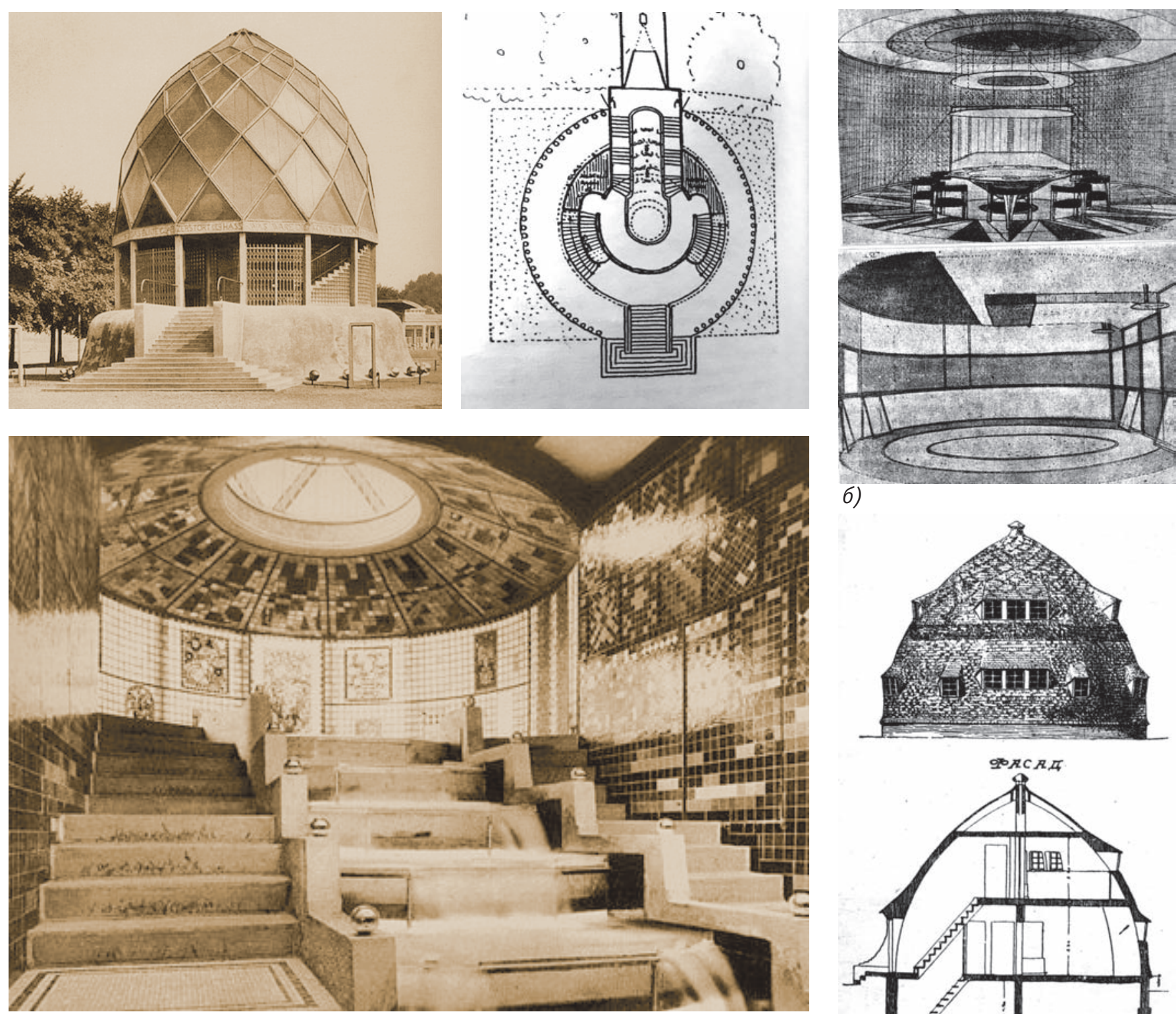

б)
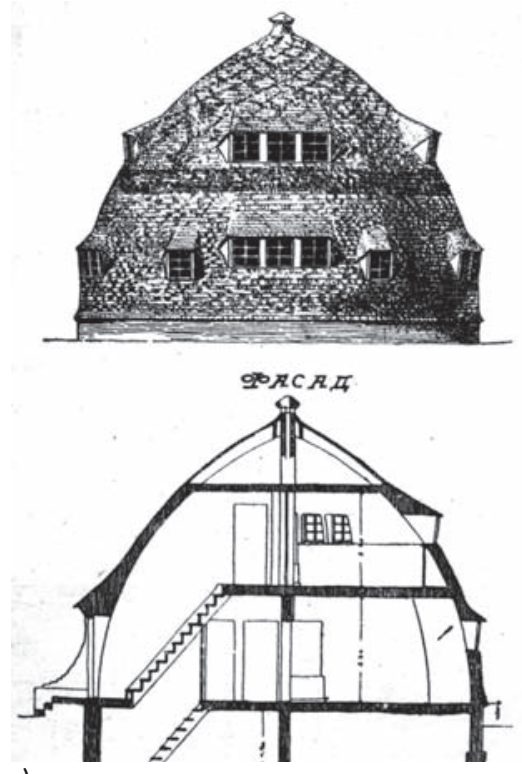

a)

B)

Рис. 10. Архитектор Бруно Таут: а) Кёльн. «Стеклянный павильон». Выставка «Немецкий Веркбунд»: общий вид, план, фойе. 1914 год; б) проект «Дома будущего»: интерьеры спальни, столовой. 1924 год; в) проект круглого жилого дома: общий вид, разрез. 1924 год
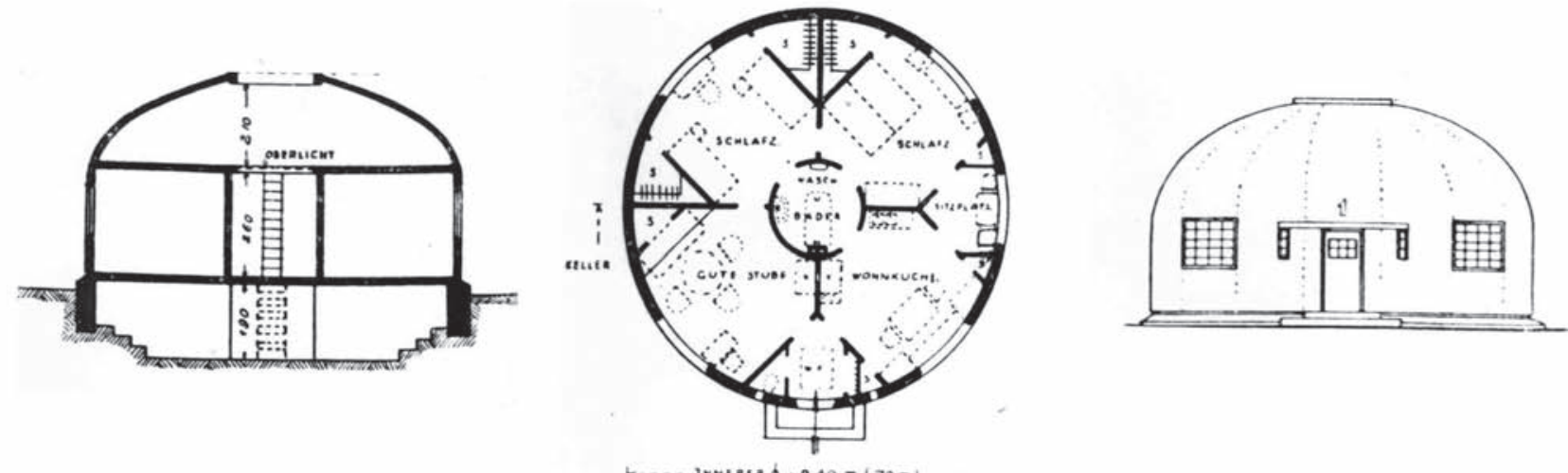

Рис. 11. Архитектор Карл Фигер. Проект круглого жилого дома: общий вид, план, разрез. 1926 год. 
архитектуры», которая, подчёркивают организаторы, не диктует условий природе, а сотрудничает с ней ${ }^{20}$.

В Центральноазиатском регионе победила унифицированная архитектура «прямых углов», безразличная к местным условиям. Внедрение опыта «новых-старых» технологий может решить целый комплекс задач. Помимо традиционно-привычных строительных приёмов, сохранившихся в сельской местности, немаловажны и экологические преимущества сырца, а также перспективы реконструкции морально и физически устаревшей современной массовой застройки - глобальной проблемы XXI века.

\section{Проектно-научная деятельность А.С. Косинского}

Как мы видели, эксперименты архитекторов авангарда позволяли совершать новаторские прорывы в диапазоне приёмов современной и традиционной культур, а объекты приобретали качество западно-восточного синтеза «разноязыких» характеристик: национальных и инонациональных, профессиональных и народных образцов.

В большей мере это было присуще проектам московского архитектора А.С. Косинского 21 . Он был воспитан на приёмах западного модернизма, доминантного послевоенного направления, благодаря той незначительной информации, которая попадала в среду советских архитекторов. Оказался в Ташкенте после землетрясения 1966 года. Ничем особенно ранее не проявивший себя, он необычайно увлёкся работой для национальной республики. Архитектора поразило, что узбекские проектировщики, отказавшись от преклонения перед памятниками средневековья, как это было в 1940 -е годы, перестали вообще обращать внимание на историческое зодчество в любом контексте, не мысля перспектив его использования.

Для А.С. Косинского толчком к этому послужило посещение Старого города. Архитектор обнаружил, что местное население избегало переезда в комфортные, как ему представлялось, современные дома, не желая терять тенистые дворики с арыками, прохладное даже в жару жильё из сырца. Позднее имели место и другие профессионально-демографические наблюдения. Многоэтажный дом-«пластина» вмещал меньше жильцов, чем махалля, занимая с междомовыми разрывами более значительную территорию22.

Отдавая должное уникальным памятникам зодчества Узбекистана, А.С. Косинский заинтересовался народной архитектурой, чьи приёмы строгой утилитарности, безотчётно ассоциировал с концептуальной основой модернизма. Как в том, так и в другом случае образное решение было производно от конструктивной логики, не отменяя своеобразную эстетику функционалистских приёмов. Архитектор-москвич был героем-одиночкой в отстаивании своих идей. Не найдя понимания в среде коллег, он сделал ставку на вузовскую молодёжь, для которой преподавал, позднее сформировав из выпускников талантливый коллектив единомышленников.

\footnotetext{
${ }^{20}$ http://taby27.ru/tvorcheskie_raboty/39/earth_architektur.html; http://www.golosarmenii.am/article/24118/zemlyanaya-arxitektura-drevnee-kamennoj-; http://archvuz.ru/2013_1/4.

${ }^{21}$ Автору статьи повезло общаться с А.С. Косинским, начиная с 1985 года.

22 Плотность традиционного домостроения была выше в три раза, чем современного, трёхэтажный дом можно приравнять к 16-этажному.
}
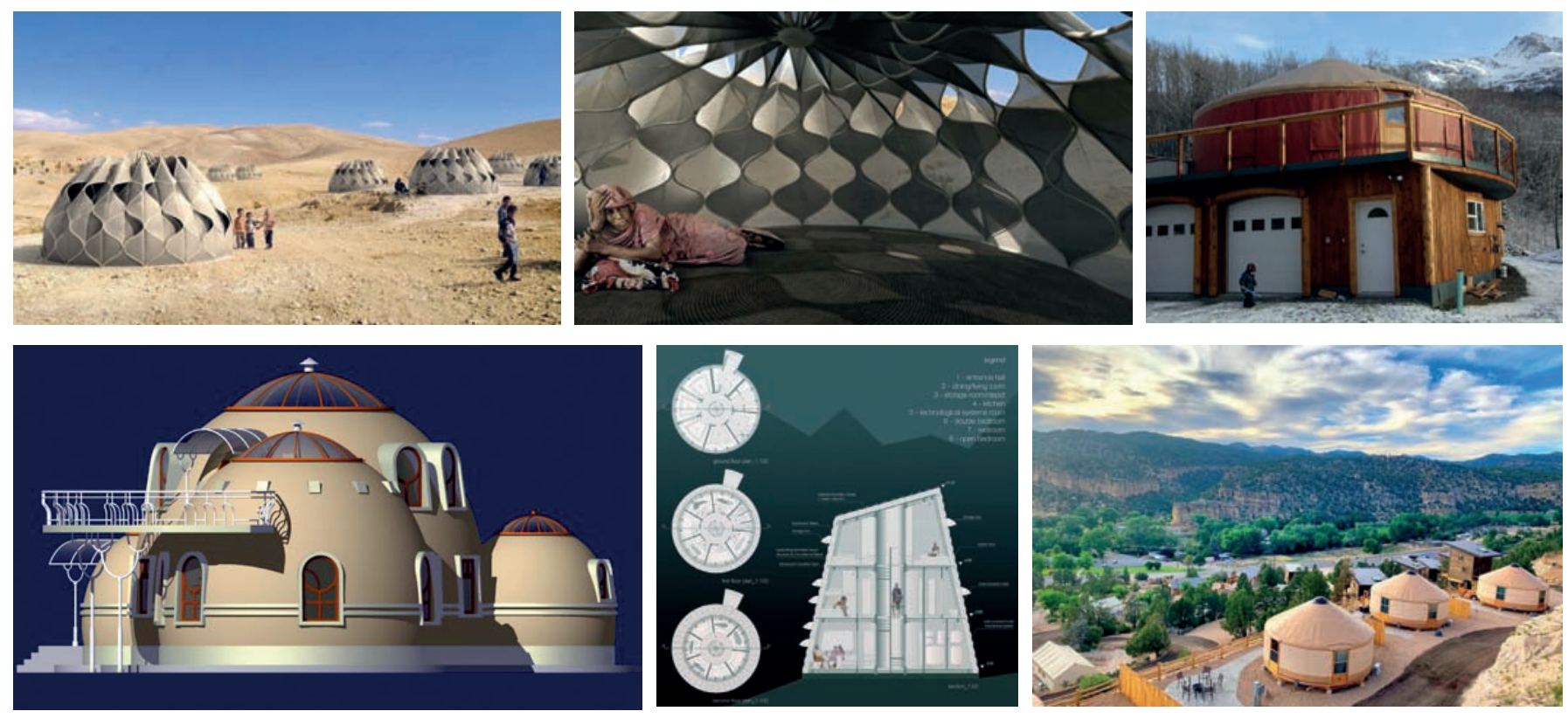

РИс. 12. Проекты современных «юрт» и переносных сезонных жилищ. Начало ХХІ века 
Подобная концепция не имела аналогов в национальных республиках. Советское зодчество лихорадочно выполняло партийные установки на реализацию планов массового жилья - стандартных по планировке, единых по облику микрорайонов на всех широтах страны. А.С. Косинский смог осуществить свои представления о специфике строительства для региона в двух комплексах на улице Богдана Хмельницкого (1971-1975) ${ }^{23}$. Применил принцип вертикальной аэрации между зданием и стеной-теплообменником с декоративными солнцезащитами. Фасады завершали развёрнутые под углом к нему сотообразные объёмы фронтально закрытых балконов, создавая дополнительное движение воздуха. Результат - температурная разница с панельным домостроением в пять градусов [29, с. 21]. Двухуровневые квартиры в домах«каскадах» имели в торцах ступенчатое объёмно-планировочное решение. 0зеленённые веранды-дворики (300 кв. м) на них, по типу висячих садов, вырабатывая охлаждающие конвекционные потоки, имели тандыры (национальные печи), арыки и бассейны. Градоформирующие и визуальные составляющие обоих типов сооружений играли не меньшую роль (рис. 13).

В проекте Центра народных художественных промыслов (Бухара, 1967-1969) А.С. Косинский впервые опробовал свои идеи по использованию опыта народной архитектуры, а не монументальных сооружений, как было до него ${ }^{24}$. А.С. Косинский использовал асимметрию традиционных белых ступенчатых объёмов, плоские кровли, принцип теплосберегающего дома-«термоса» ${ }^{25}$. Увязаны с наследием факторы средообразования, формирующие ансамбль с примыкающими жилыми кварталами, а пространственные векторы ориентировали здание на историко-культурные доминанты (памятники XV-XIX веков). Объект мог стать необычайно привлекательным для туристов, ремесленников (узбекских усто) (рис. 14).

Стремясь преодолеть однообразие типового домостроения микрорайонов, А.С. Косинский подготовил проект

${ }^{23}$ В недавней книге Филиппа Мойзера преувеличены творческие аспекты типовой застройки Ташкента: Мекка панельного домостроения, взгляд в сторону Запада, влияние Ле Корбюзье. Отметив «национальный» (что неверно) характер декора и системы вентиляции дома, исследователь игнорировал наиболее важное - концептуальные установки проектной деятельности А.С. Косинского, вопреки интригующему названию морально устаревшего труда [29].

${ }^{24}$ Воплотил теорию, что при проектировании надо умело сочетать факторы места (традиции) и времени (современность).

${ }^{25}$ Образно-функциональные приёмы сооружения аналогичны решению тогда забытого проекта Физического института (арх. А. и Л. Веснины, 1927) (см. рис. 3 а, б).
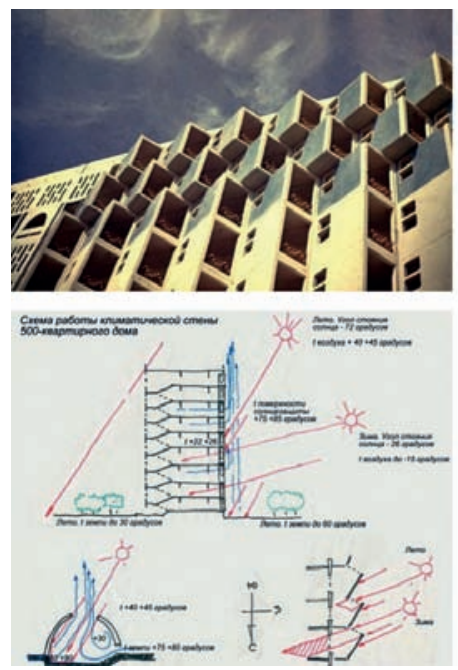

a)

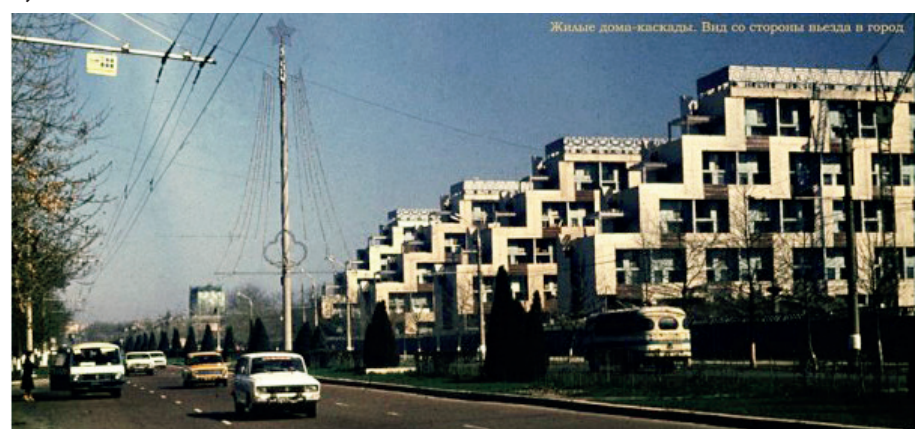

б)
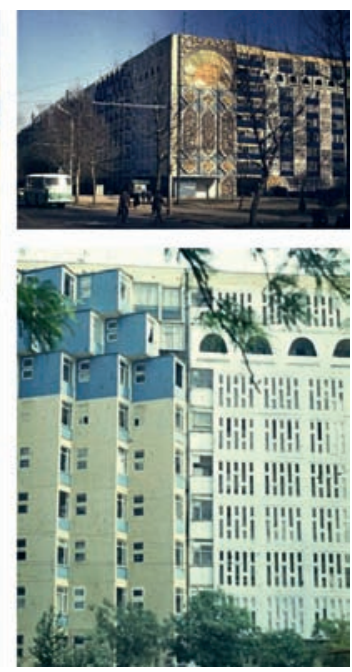
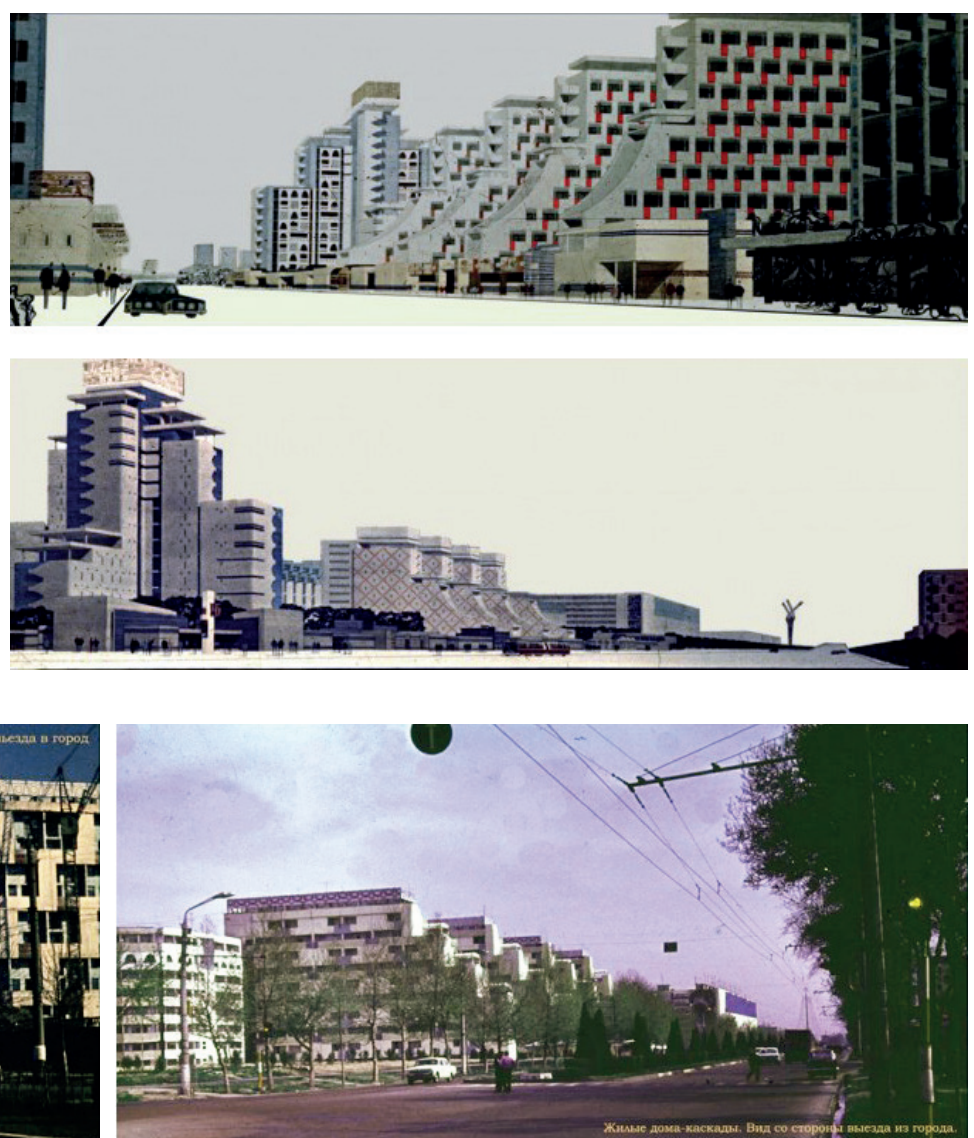

Рис. 13. Ташкент Архитектор А.С. Косинский: а) жилой дом с «климатической стеной» на улице Богдана Хмельницкого. 1971-1975 годы. Перспектива, решение лоджий, схема работы стены (рисунокА.С. Косинского, 1971); б) вид нажилыедома-«каскады» наулице Богдана Хмельницкого. Проектный материал, перспектива застройки со стороны въезда в город и по дороге в аэропорт. 1977 год 
22-этажного здания-«минарета» гостиницы (1970) - высотной доминанты Чиланзара. Архитектор предложил проект наиболее рационального в условиях высокой сейсмики, круглого в плане сооружения по типу «ваньки-встаньки» с двухметровой прослойкой воды под ним (дом-«поплавок») и громадным атриумом внутри. Профили солнцерезов, служа образно-пластическому насыщению фасадов, были функционально и конструктивно дифференцированы в связи с ориентацией здания, геометрией движения солнца в течение дня и по сезонам (вариант «климатической стены»). Ещё одна нереализованная идея - сделать здание вращающимся ${ }^{26}$. Архитектурный замысел расценили плодом беспочвенной фантазии автора. Подобное объёмно-конструктивное решение получило гораздо более позднее воплощение в США: «портмоновские» атриумы, проекты «плавающих домов» ${ }^{27}$ (рис. 15).

В продолжение своих разработок А.С. Косинский предложил концепцию проекта жилого квартала «Калькауз» в Старом городе (1974-1978). Масштабная проектно-научная работа базировалась на знаниях архитектора-профессионала и исследовательских материалах его коллектива по народному жилищу в зоне исторической застройки. Нашли применение характерные для Азии градоформирующие планировочные структуры взаимосвязанных пространств из тесно сгруппированных, подобных сотам, комплексов, которые пересекала Торговая улочка, важный атрибут повседневной жизни Востока. Апробированные строительством многоэтажные жилые дома-«каскады» и здания-«минареты» формировали территориальный и визуальный периметр новаторского по облику квартала.

Исторический приём по укрупнению кварталов махалли, заключавшийся в пристраивании дома к уже имеющимся, подтолкнул автора к идее, так называемых, растущих асимметричных трёхэтажных жилых структур, которые для экономии территории наращивались по вертикали. Объёмы малоэтажных зданий ${ }^{28}$ визуально были акцентированы в высоту выразительными конструктивными элементами: аркадами входной группы, системой арочных перекрытий. В регионе, где кровли в жилье делают плоскими, арки «Калькауза» стали нетрадиционным образным и функционально оправданным приёмом, позволяющим смягчать микроклимат за счёт активного перемещения воздушных потоков в интерьерах. Открытость этих домов улице также была вне азиатской традиции. Сама же методика освоения, без копирования наследия, создавала перспективы для его развития в контексте профессиональной

\footnotetext{
${ }^{26}$ A.С. Косинский сравнивал свой проект с появившимся позднее домом«огурцом» швейцарской страховой компанией (арх. Норман Фостер).

${ }^{27}$ Доклад А.С. Косинского «Моя работа в Ташкенте в 1966-1980 гг. В рамках "Последнего съезда архитекторов СССР"». Вена, 24 ноября 2012 года (источник: https://a-s-kosinskiy.livejournal.com/).

${ }^{28}$ Данный проект всё-таки был реализован в комплексе на улице Бируни. Правда, здания скрыты за высотными домами. Аналогичный приём в те же годы использовал в Алжире архитектор Ж. Кандилис.
}

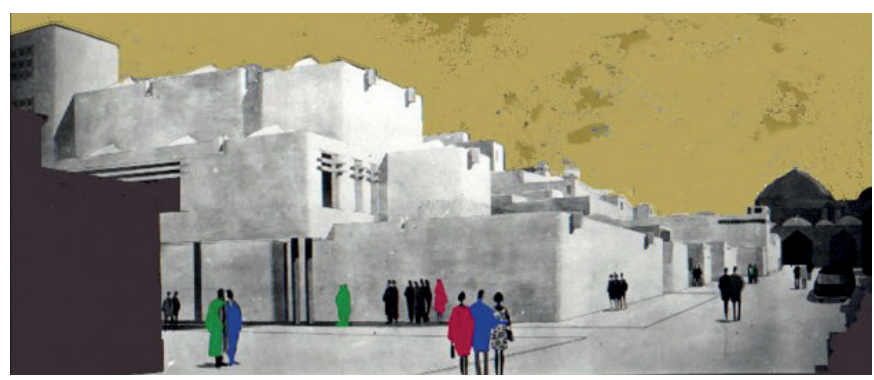

Рис. 14. Бухара. Центр народных художественных промыслов. Проект. Архитектор А.С. Косинский. 1967-1969 годы

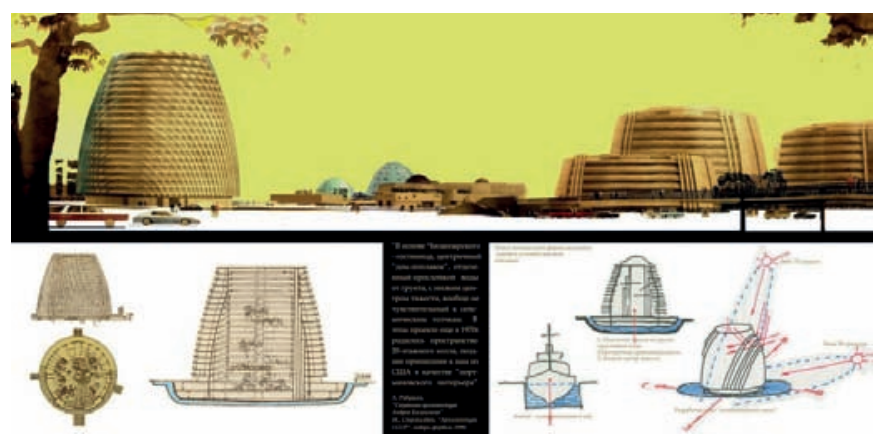

Рис. 15. 22-этажное здание-«минарет» гостиницы. Проект. Рисунок А.С. Косинского. 1970 год: общий вид, разрезы здания-«поплавка», схема солнцезащит
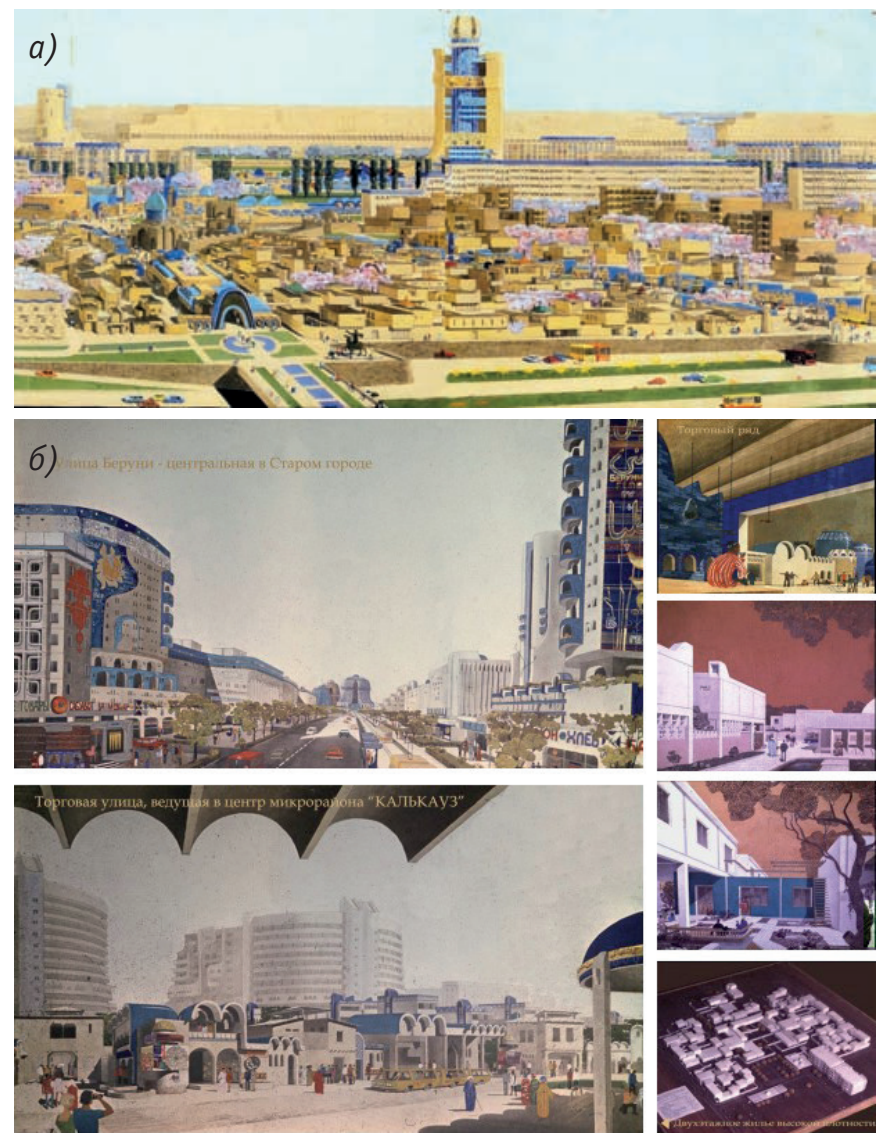

Рис. 16. Жилой квартал «Калькауз». Проект. Архитектор А.С. Косинский. 1974-1978 годы: а) перспектива застройки Старого города; б) панорама центральной улищы, общий вид «Торговой улицы», фрагменты застройки, макет квартала 
культуры, в свою очередь, расширяя её диапазон. Проект, как говорил автор, был принят, утверждён и забыт ${ }^{29}$ (рис. 16).

Осуществлённым объектом в проекте «Калькауз» стала баня «Хамам» (1971-1975). Этим объясняется островное положение сооружения, не подкреплённого застройкой неосуществлённого микрорайона. Без бани просто немыслима жизнь восточного города. По словам архитектора, он избегал ассоциаций с заглублённой в землю для сохранения тепла сумрачной азиатской баней, выполнив современное сооружение, не имевшее аналогов в мировом зодчестве, благодаря целому ряду уникальных конструктивно-инженерных предложений (рис. 17, 18).

Важнейшее достоинство бани «Хамам»- свободные от стилизации новаторские функционально-образные приёмы, использующие традиционные материалы и технологии. Были

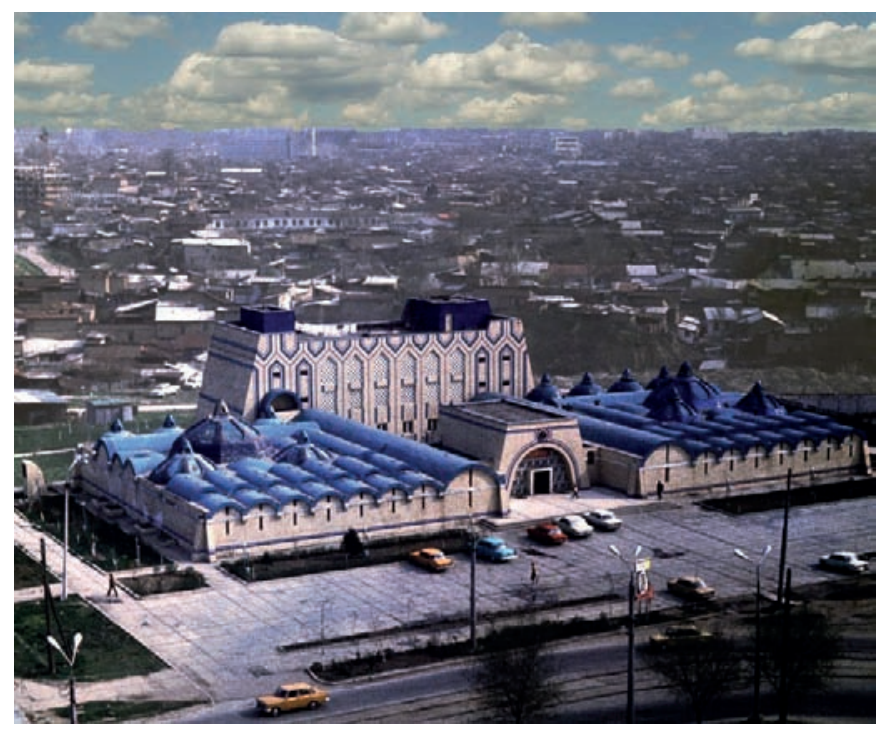

Рис. 17. Ташкент. Вид на баню «Хамам» и прилегающую застройку. Архитектор А.С. Косинский

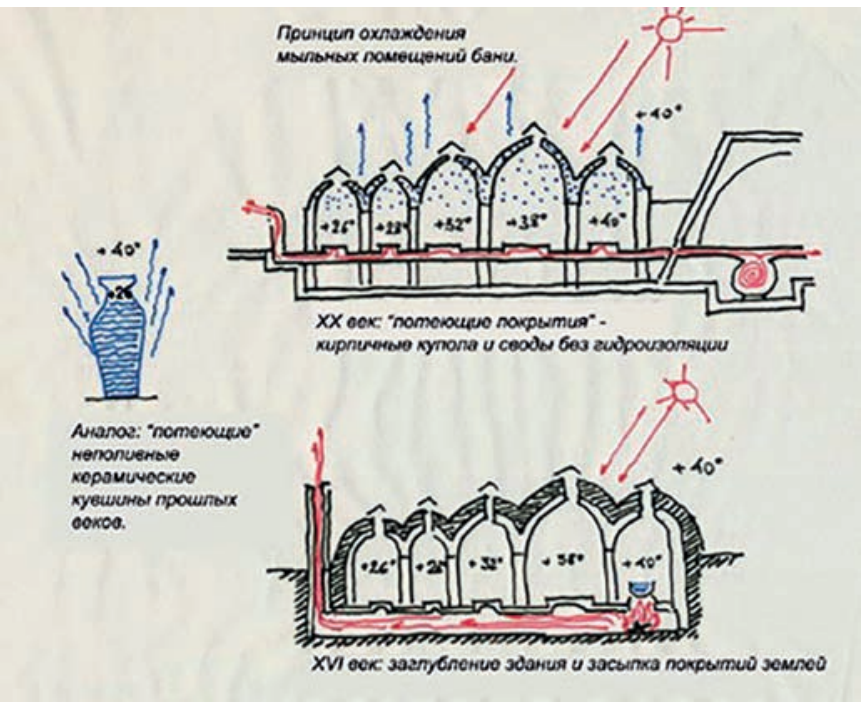

Рис. 18. Принцип охлаждения помещений. Проект: принцип и схемы устройства сводов. Рисунок А.С. Косинского выведены наружу конструктивные основы региональных сооружений, обычно скрытые в интерьерах, прежде всего, купола и система арок перекрытий. Помимо функциональной нагрузки - идея «потеющего дома» за счёт термовлажностного решения кровли, - они сыграли важную роль в образной характеристике объекта. Не менее значим и керамический орнаментальный декор, украсивший не только переосмысленный пештак (азиатский портал над входом), но и визуально дублирующий массивный объём основного здания со вспомогательной группой помещений. К сожалению, технические, стилевые находки, доказав правильность проектного замысла и расчётов не были до конца поняты и оценены ${ }^{30}$ (рис. 19).

А.С. Косинский совершил собственную творческую эволюцию, преодолев установки модернизма. Решение здания бани «Хамам» вызвало у многих недоумение - к какой профессиональной категории его отнести. Спустя годы стало очевидно - это было программное сооружение постмодернизма ${ }^{31}$, первый пример в советском зодчестве (как, впрочем, гостиница-«минарет», но всё-таки она осталась проектом). Бесспорно, архитектор и в данном случае обогнал время ${ }^{32}$.

Архитектора нельзя подозревать в «новом регионализме» (3. Гидион). А.С. Косинский свою версию теоретического принципа «гения места» (Genius Lozi) чётко сформулировал: «Поиск современных решений лежит не в глобальных архитектурных стилях, не в архитектурной периодике, не в архитектурной моде, но в точных ориентирующих пространственно-временных факторах конкретного места строительства, глядя на неё, как бы, со стороны»33.

\footnotetext{
${ }^{29}$ https://www.fergananews.com/articles/4430;

https://www.fergananews.com/articles/4524;

https://www.fergananews.com/articles/8939.
}

${ }_{30}$ Расположенная на границе «Старого города», не смотря на экзотичность облика, «Хамам» стала предметом гордости у местных жителей. На собранные ими средства к открытию бани был устроен настоящий праздник с процедурой освящения, национальной музыкой, танцами, достарханом. Это психологически компенсировало буквально травлю автора местным начальством и Госстроем СССР.

${ }^{31}$ Сам А.С. Косинский так не считал, называя себя архитектурным диссидентом. Автор статьи оставляет за собой право отнести его работы к постмодернизму.

32 Полный разочарования от крушения надежд на реализацию своих проектов, А.С. Косинский вернулся в Москву, где, по его словам, вновь погрузился в профессиональную рутину. Лучшими всегда считал годы работы в Ташкенте. Скорее для того, чтобы осмыслить свой азиатский опыт, а не во имя научной карьеры, архитектор изложил анализ проделанного в диссертации [28]. Зарубежное профессиональное сообщество высоко оценило его труды. Тема пространственно-временного генезиса архитектурной формы (на основе проектов ташкентского периода) была доложена автором, награждённым Золотой медалью, на Всемирном бьеннале архитектуры «Интерарх 83». А далее было то, что можно назвать «осенью патриарха». Незадолго до ухода из жизни архитектор с горечью рассказал мне, как уничтожили его сооружения: баню «Хамам» снесли ради автостоянки, террасы жилых «домов-каскадов» надстроили для новых квартир. Расправа над наследием тех лет, занявшем достойное место в истории мировой архитектуры XX века, забвение труда их авторов проходит повсеместно в постсоветской социокультурной реальности.

${ }^{33}$ https://a-s-kosinskiy.livejournal.com/. 
Десятилетия спустя состоялось знаковое событие - XIX Венский Архитектурный конгресс на фоне выставки «Советский модернизм 1955-1991. Неизвестные истории» (2012). Он открыл международному профессиональному сообществу высокую художественную ценность зодчества советской империи, реабилитировав, в частности, и идеи А.С. Косинского. Его доклад-исповедь оказался в центре внимания научной дискуссии ${ }^{34}$, обнаружив переоценку значимости его творчества, как одного из выдающихся мастеров эпохи модернизма.

Архитектура национальных республик Центральной Азии демонстрировалась в дальнейшем на выставках в Стамбуле, Лейпциге, Москве, Петербурге, Сан-Пауло, Венеции (2012-2014). Творческий диапазон экспозиций был расширен материалами по архитектуре стран, ранее пребывавших вне научно-творческого интереса: Индии, Латинской Америки, Северной Африки, Юго-Восточной Азии. Сопровождавшая выставки научная полемика (конференции, пресса, исследования) аргументированно доказала, что архитектура модернизма этих государств демонстрирует жизнестойкость культурных традиций, которые не только спасли профессиональную деятельность от шаблона средств и решений, но и сформировали самобытность современных национальных школ.

Приведённый материал по зарубежной и центральноазиатской архитектуре позволяет прийти к определённым выводам. Архитектура новых столиц молодых национальных государств XX века демонстрирует значительную долю прогностических параметров творчества, предвосхищая будущее. Социокультурные критерии проектной работы вырабатывали новые формы жизнеустройства общества. Проекты могли стать парадом идей по формированию идеальных городов неведомого «завтра», оторванных от традиционной культуры, как у 0. Нимейера. Опережающий время утопизм архитектурного замысла демонстрировал стремление проектировщиков учитывать местные реалии (экологические, историко-культурные): генплан Канберры, идеи соцгородов и проекты для «оседающих кочевников» Центральной Азии, планировка и стилистика Чандигарха, научно-исследовательские и проектные работы А.С. Косинского.

Синтез современных и исторических образцов, без подражания им, усиливал жизнеспособный потенциал проектов. Методологические критерии связаны с принципами модернизма и постмодернизма: «несерьёзные» дома-«кибитки» В. Калмыкова, дом-«минарет» и сооружения «Калькауза» А. Косинского. Тем самым складывались инновационные параметры проектной деятельности, появление некоего «третьего» явления - новаторского, как для исторического наследия, так и современности. Подобные установки про-

${ }^{34}$ Дискуссию шутливо назвали «Последний съезд архитекторов СССР», завершив конгресс петицией, признававшей значимость архитектурного наследия советского модернизма, его изучения и сохранения (источник: Новиков Ф. Слово о Венском конгрессе. Мнение. 06 Декабря 2012. - https:// archi.ru/world/45153/slovo-o-venskom-kongresse). слеживались, начиная с построек зарубежных модернистов (Бруно Таут и другие), проектов русского авангарда для Туркестана 1920-1930-х годов, а в дальнейшем - в послевоенной отечественной и зарубежной архитектуре Австралии, стран восточного ареала - Центральной Азии, Индии.

Одновременно разрабатывались концептуальные приёмы, расширяющие горизонты профессии и личного творчества архитекторов: брутализм Ле Корбюзье, уход от эстетики геометрически упрощенных форм к пластической свободе символических структур 0. Нимейера, модернистские и постмодернистские эксперименты А.С. Косинского.

35 Подробный анализ архитектуры Алма-Аты будет дан в отдельной публикации в одном из ближайших номеров журнала «Академия. Архитектура и строительство».

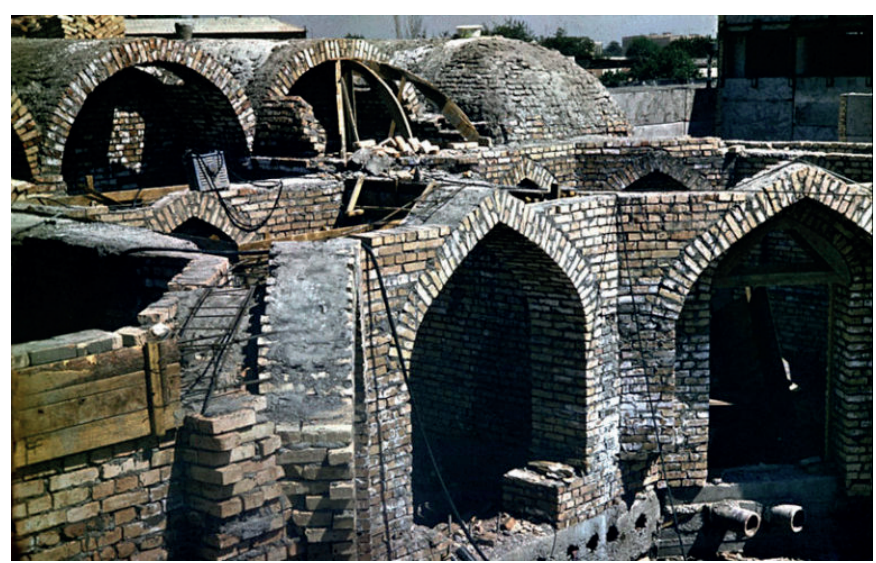

a)

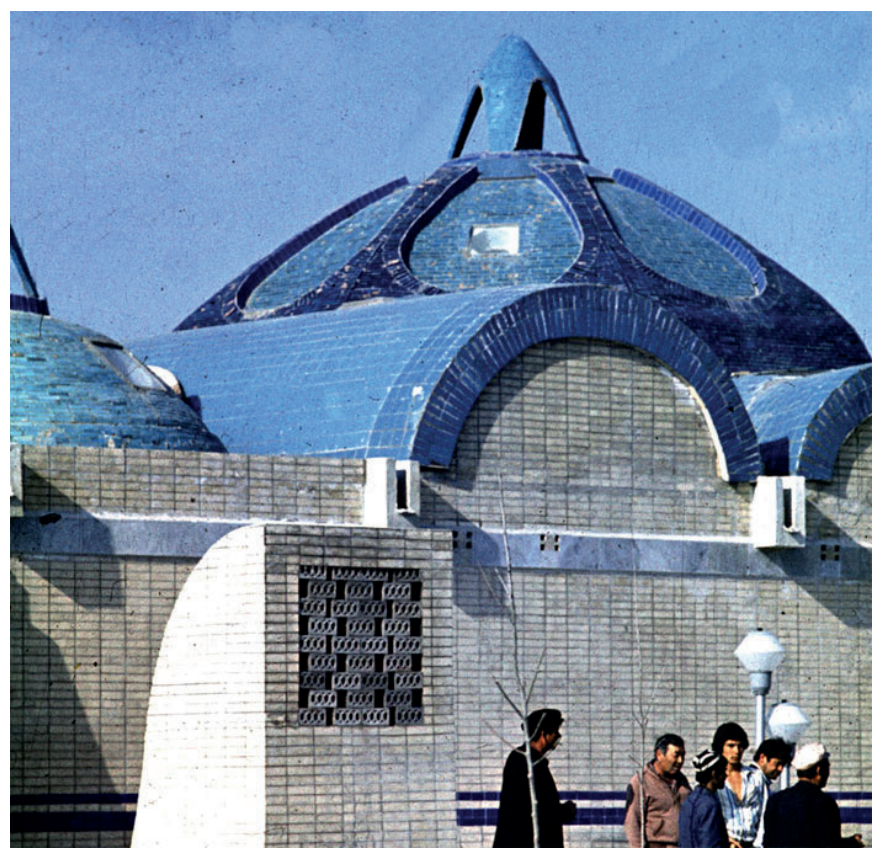

б)

Рис. 19. Ташкент. Баня «Хамам». Архитектор А.С. Косинский. 1971-1975 годы: общий вид системы куполов и сводов в процессе строительства; б) фрагмент сооружения - система сводчато-купольного решения и вентиляции здания 
Для Австралии и Казахстана в их столицах - Канберре и Алма-Ате ${ }^{35}$ - осуществлялись сходные процессы становления национальных школ. Сложность включения кочевого наследия в современную культуру стимулировала независимость от исторических образцов, которые обычно довлеют, лишая инициативы архитектора-профессионала. Путём адаптации и постепенной трансформации инонациональных образцов создавались профессионально-творческие модели в связи с социокультурными установками этих стран. Это был непростой опыт. Но постепенно вырабатывалась шкала ценностных ориентиров, актуализирующих роль определённых этапов или знаковых сооружений данной национальной школы. Наличие ссылок на них сформировало параметры традиций, хотя и не отстоящих далеко во времени - современных, - тем не менее собственно-национальных. То, что изначально воспринималось слабостью этих национальных школ, задало векторы для их активности и самореализации.

Переосмысление историко-культурного опыта представителем инонациональной культуры - взгляд «извне» - освобождает от стереотипов его восприятия носителем национального наследия. Таким образом, «чужая» традиция выступает для архитектора как новация. Принадлежность к профессиональной культуре позволяет с лёгкостью входить в систему иной традиции («места»), трансформируя её в соответствии с установками и задачами проектирования («времени»).

Инновационная методика освоения исторического опыта, свободная от подражания, создаёт перспективы для развития традиций в контексте современности, одновременно обогащая профессию творческими открытиями как на уровне индивидуальных достижений мастеров, так и в целом архитектуры XX века.

\section{Лuтература}

1. Аинса, Ф. Нужны ли нам утопии // Курьер ЮНЕСКО. -1991. Апрель.

2. Бабиевский, К.В. На неверном пути / К.В. Бабиевский // Архитектурная газета. - 1937. - 28 сентября. - № 67. - С. 2; Мазманян М.0. 0 национальной архитектуре / М.0. Мазманян // Печать и революция. - 1929. - №7. - С. 80; Михайлов Г. Группировки советской архитектуры / Г. Михайлов. - М.-Л., 1932. - С. 26; Р. и Ч. Национальная архитектура в Средней Азии / Р. и Ч. // Искусство в массы. - 1930. - № 8 (16). - С. 10-11.

3. Малиновская, Е.Г. Памятник современной архитектуры / Е.Г. Малиновская. Серия «Наследие советской эпохи. Избранные труды». - Алматы : ARK Gallery, 2018. - 488 с.

4. Гинзбург, М.Я. Дом правительства в Алма-Ате (КАССР)/ М.Я. Гинзбург // Современная архитектура. - 1928. - № 3. С. 75-77; Гинзбург, М.Я. Национальная архитектура народов СССР / М.Я. Гинзбург // Современная архитектура. - 1926. - № 5-6. - С. 113-114; Гинзбург, М.Я. Жилище: опыт пятилетней работы над проблемой жилища / М.Я. Гинзбург. - М. : Госстройиздат, 1934. - 192 с.

5. Лавров, В. К проблеме реконструкции городов в усло- виях Средней Азии / В. Лавров, В. Попов // Советская архитектура. - 1931. - № 3. - С. 30-37; 1931. - № 4. - С. 38-44.

6. Калмыков, В. Чарджуй / В. Калмыков, Л. Гришпун // Советская архитектура. - 1931. - №1-2; С. 36-43; Хазанова В.Э. Советская архитектура первой пятилетки. Проблемы города будущего / В.Э. Хазанова. - М. : Наука, 1980. - С. 93, 148-149.

7. Малиновская, Е.Г. Молодые национальные школы XX века: культурная идентичность или концептуальный выбор? / Е.Г. Малиновская // Искусствознание: наука, опыт, просвещение : Сборник статей по материалам международной научной конференции. 9-11 ноября 2017 года / Ред.-сост. Г.У. Лукина. - М. : ГИИ, 2018.

8. Осипов, П. Стандартное круглое здание для сельскохозяйственного посёлка / П. Осипов // Строительство Москвы. - 1930. - № 5.

9. Малиновская, Е.Г. Формирование профессиональной архитектуры Казахстана. Дис. ... канд. искусствоведения. В 3-х т. Т. 1. - М., 1989. - С. 26-29.

10. Хаирхан. Социалистическое переселение Азии / Хаирхан // Революция и культура. - 1930. - № 2. - С. 45-46.

11. Хаирхан. Социалистическое расселение Азии / Хаирхан // Революция и культура. - 1930. - № 1. - С. 61-66.

12. Хигер, Р.Я. К проблеме экономического обоснования проектирования жилища / Р.Я. Хигер, К.К. Джус // Строительная промышленность. - 1929. - № 8. - 673 с.

13. Белоусов, В.Я. К вопросу о социалистическом расселении в Киргизской АССР / Белоусов В.Я., Рысс Ц.Г., Калмыков В.П. / Киргизская комплексная экспедиция 1932-1933 гг. : Сб. научн. Трудов. Т. V, вып.1. - М.-Л. : Изд-во АН СССР, 1935. - 79 с., карты, фот.

14. Калмыков, В. Проект центрального физкультурного комбината Средней Азии / В. Калмыков // Архитектура СССР. - 1935. - № 6. - С. 43-47.

15. Бунин, А. Жилище для оседающих кочевников Кирреспублики / А. Бунин // Архитектура СССР. - 1933. - № 5.

16. Маньковская, Л.Ю. Типологические основы зодчества Средней Азии (IX - начало XX веков) / Л.Ю. Маньковская. Ташкент : Фан, 1980. - 182 с.

17. Малиновская, Е.Г. Социальные и этнокультурные последствия процесса «оседания кочевников» / Е.Г. Малиновская // Национальные образы мира в художественной культуре. Материалы Международной научной конференции, посвящённой 85-летию со дня рождения литературоведа, философа, культуролога Г.Д. Гачева (1929-2008). 24-27.10.2014. - Нальчик : Издательство М. и В. Котляровых (000 «Полиграфсервис и Т»), 2015. - 728 с.

18. Крутиков, Г. Круглое и полукруглое жилище / Г. Крутиков // Строительная промышленность. - 1927. - № 9. - С. 617-620; Лухманов, Н. Цилиндрический дом / Н. Лухманов // Строительство Москвы. - 1929. - № 5. - С. 16-22.

19. КГБ: вчера, сегодня, завтра / III Международная конференция - Общественный фонд «Гласность». Фонд «Культурная инициатива», 1-3 октября 1993 г. - М. : Знак-СП, 1994. - 303 с. 
20. Малиновская, Е.Г. Репрессированная архитектура сталинские новостройки, творчество и судьбы архитекторов / Е.Г. Малиновская; Серия «Наследие советской эпохи. Избранные труды». - Алматы : ARK Gallery, 2018. - 479 с. - С. 20-24.

21. Gesamtkunstwerk Сталин // Борис Гройс. Искусство утопии. - М : ХЖ, 2003. -319 с.

22. Голицын С. Записки уцелевшего : Роман / С. Голицын. - М. : Орбита, 1990. - 736 с.

23. Новое дачное строительство // Строительство Москвы. - 1933. - № 7.

24. Поворот в архитектуре к Востоку // Строительная промышленность. - 1925. - № 8. - С. 561.

25. Вольфензон Г. Жилищная культура / Г. Вольфензон // Строительная промышленность. - 1925. - № 6-7. - С. 471-475.

56. Effimero per vacanse // Domus. - 1975. - № 544. - P. 33-36.

27. An American Dream House // Domus. -1980. - № 610. - P. 42-43; Wright, D. Notes on Energy in Home Design / David Wright // Architecture and Urbanism. - 1982. - P. 87-89; Temporary Houses // Architectural Design. - 1978. - № 4. - P. 234-235;

28. Косинский А.С. Архитектурная форма в зависимости от факторов места и времени (на примере авторских работ 1960 1980-х годов) : Автореф. дис. ... канд. архит. - М., 1984.

29. Мойзер Филипп. Сейсмический модернизм. Архитектура и домостроение советского Ташкента. Теория и история / Филипп Мойзер. - Берлин : DOM publishers, 2017. - 256 с.

\section{References}

1. Ainsa F. Nuzhnyli nam utopii [Do we need utopias]. In: Kur'er YUNESKO [The UNESCO Courier], 1991, April.

2. Babievskii K.V. Na nevernom puti [On the wrong path]. In Arkhitekturnaya gazeta, 1937, 28 September. No. 67, p. 2; Mazmanyan M.0. 0 natsional'noi arkhitekture [0n national architecture]. In: Pechat' i revolyutsiya [Print and revolution], 1929, no.7, pp. 80; Mikhailov G. Gruppirovki sovetskoi arkhitektury [Groupings of Soviet architecture]. Moscow-Leningrad, 1932, p. 26; R. and Ch. Natsional'naya arkhitektura v Srednei Azii [National architecture in Central Asia]. In: Iskusstvo $v$ massy [Art to the masses], 1930, no. 8 (16), pp. 10-11.

3. Malinovskaya E.G. Pamyatnik sovremennoi arkhitektury [Monument of modern architecture]. Almaty, ARK Gallery Publ., 2018, 488 p.

4. Ginzburg M.Ya. Dom pravitel'stva v Alma-Ate (KASSR) [Government House in Alma-Ata (KASSR)]. In: Sovremennaya arkhitektura [Modern architecture], 1928 no. 3, pp. 75-77; Ginzburg M.Ya. Natsional'naya arkhitektura narodov SSSR [National architecture of the peoples of the USSR]. In: Sovremennaya arkhitektura [Modern architecture], 1926, no. 5-6, pp. 113-114; Ginzburg M.Ya. Zhilishche: opyt pyatiletnei raboty nad problemoi zhilishcha [Housing: 5 years of experience working on the housing problem]. Moscow, Gosstroiizdat Publ., 1934, 192 p.

5. Lavrov V., Popov V. K probleme rekonstruktsii gorodov v usloviyakh Srednei Azii [0n the problem of urban reconstruction in the conditions of Central Asia]. In: Sovremennaya arkhitektura [Modern architecture], 1931, no. 3, pp. 30-37; 1931, no. 4, pp. 38-44.

6. Kalmykov V., Grishpun L. Chardzhui. In: Sovremennaya arkhitektura [Modern architecture], 1931, no.1-2, pp. 36-43; Khazanova V.E. Sovetskaya arkhitektura pervoi pyatiletki. Problemy goroda budushchego [Soviet architecture of the first five-year plan. The problems of the city of the future]. M., Nauka Publ., 1980, pp. 93, 148-149.

7. Malinovskaya E.G. Molodye natsional'nye shkoly XX veka: kul'turnaya identichnost' ili kontseptual'nyi vybor? [Young National Schools of the 20th Century: Cultural Identity or Conceptual Choice?]. In: Iskusstvoznanie: nauka, opyt, prosveshchenie. Sbornik statei po materialam mezhdunarodnoi nauchnoi konferentsii, 9 noyabrya 2017 goda [Art: science, experience, education. Collection of articles based on the materials of the international scientific conference, 9 November, 2017]. Moscow, GII Publ., 2018.

8. Osipov P. Standartnoe krugloe zdanie dlya sel'skokhozyaistvennogo poselka [Standard round building for agricultural settlement]. In: Stroitel'stvo Moskvy [Construction of Moscow], 1930, no. 5.

9. Malinovskaya E.G. Formirovanie professional'noi arkhitektury Kazakhstana [Formation of professional architecture in Kazakhstan]. Dis. ... kand. Iskusstvovedeniya, In 3 volumes, Vol. 1. Moscow, 1989, pp. 26-29.

10. Khairkhan. Sotsialisticheskoe pereselenie Azii [Socialist resettlement of Asia]. In: Revolyutsiya i kul'tura [Revolution and culture], 1930, no. 2, pp. 45-46.

11. Khairkhan. Sotsialisticheskoe rasselenie Azii [Socialist settlement of Asia]. In: Revolyutsiya i kul'tura [Revolution and culture], 1930, no. 1, pp. 61-66.

12. Khiger R.Ya., Dzhus K.K. K probleme ekonomicheskogo obosnovaniya proektirovaniya zhilishcha [To the problem of the economic justification of the design of a dwelling]. In: Stroitel'naya promyshlennost' [Construction industry], 1929, no. 8, pp. 673.

13. Belousov V.Ya., Ryss Ts.G., Kalmykov V.P.K voprosu o sotsialisticheskom rasselenii $\vee$ Kirgizskoi ASSR [0n the issue of socialist settlement in the Kyrgyz ASSR]. Kirgizskaya kompleksnaya ekspeditsiya 1932-1933 gg. Sb. nauchn. trudov [Kyrgyz complex expedition 1932-1933. Coll. of scientific proceedings], Vol. V, Iss.1. Moscow-Leningrad, Izd-vo AN SSSR Publ., 1935, 79 p.

14. Kalmykov V. Proekt tsentral'nogo fizkul'turnogo kombinata Srednei Azii [Project of the Central Physical Culture Combine of Central Asia]. In: Arkhitektura SSSR [Architecture of the USSR], 1935, no. 6, pp. 43-47.

15. Bunin A. Zhilishche dlya osedayushchikh kochevnikov Kirrespubliki [Dwelling for the settling nomads of the Kirpublic]. In: Arkhitektura SSSR [Architecture of the USSR], 1933, no. 5.

16. Man'kovskaya L.Yu. Tipologicheskie osnovy zodchestva Srednei Azii (IX- nachalo XX vekov) [Typological foundations of architecture in Central Asia (IX - early XX centuries)]. Tashkent, Fan Publ., 1980, 182 p. 
17. Malinovskaya E.G. Sotsial'nye i etnokul'turnye posledstviya protsessa «osedaniya kochevnikov» [Social and ethnocultural consequences of the process of "settling of nomads"]. In: Natsional'nye obrazy mira $v$ khudozhestvennoi kul'ture. Materialy Mezhdunarodnoi nauchnoi konferentsii, posvyashchennoi 85-letiyu so dnya rozhdeniyaliteraturoveda, filosofa, kul'turologa G.D. Gacheva (1929-2008) [National images of the world in artistic culture. Materials of the International Scientific Conference dedicated to the 85th anniversary of the birth of theliterary critic, philosopher, culturologist G.D. Gachev (1929-2008)]. 24-27.10.2014. Nal'chik, Publishing house of M. i V. Kotlyarovykh (000 "Poligrafservis i T"), 2015, 728 p.

18. Krutikov G. Krugloe i polukrugloe zhilishche [Round and semicircular dwelling]. In: Stroitel'naya promyshlennost' [Construction industry]. 1927, no. 9, pp. 617-620; Lukhmanov N. Tsilindricheskii dom [Cylindrical house]. In: Stroitel'stvo Moskvy [Construction of Moscow], 1929, no. 5, pp. 16-22.

19. KGB: vchera, segodnya, zavtra. III Mezhdunarodnaya konferentsiya - Obshchestvennyi fond «Glasnost'». Fond «Kul'turnaya initsiativa» [KGB: Yesterday, Today, Tomorrow / III International Conference - Public Foundation "Glasnost". Fund "Cultural Initiative"], 1-3 oktyabrya 1993 g. Moscow, Znak-SP Publ., 1994, 303 p.

20. Malinovskaya E.G. Repressirovannaya arkhitektura - stalinskie novostroiki, tvorchestvo i sud'by arkhitektorov [Repressed architecture - Stalinist new buildings, creativity and destinies of architects]. Almaty, ARK Gallery Publ., 2018, 479 p., pp. 20-24.

21. Gesamtkunstwerk Stalin. In: Boris Grois. Iskusstvo utopii [Boris Groys. The art of utopia]. Moscow, "KhZh" Publ., 2003, 319 p.

22. Golitsyn S. Zapiski utselevshego [Notes of the Survivor]. Moscow, Orbita Publ., 1990, 736 p.

23. Novoe dachnoe stroitel'stvo [New dacha construction]. In: Stroitel'stvo Moskvy [Construction of Moscow], 1933, no. 7.

24. Povorot $v$ arkhitekture $\mathrm{k}$ Vostoku [Turn in architecture to the Ease]. In: Stroitel'naya promyshlennost' [Construction industry], 1925, no. 8, 561 p.

25. Vol'fenzon G. Zhilishchnaya kul'tura [Housing culture In: Stroitel'naya promyshlennost' [Construction industry], 1925, no. $6-7$, pp. $471-475$.

26. Effimero per vacanse. In: Domus, 1975, no. 544, pp. 33-36.

27. An American Dream House. In: Domus, 1980, no. 610, pp. 42-43; David Wright. Notes on Energy in Home Design. In: Architecture and Urbanism, 1982, pp. 87-89; Temporary Houses. In: Architectural Design, 1978, no. 4, pp. 234-235.

28. Kosinskii A.S. Arkhitekturnaya forma v zavisimosti ot faktorov mesta i vremeni (na primere avtorskikh rabot 1960 1980-kh godov) [Architectural form depending on the factors of place and time (on the example of author's works of the 1960s-1980s)], Avtoref. dis. ... kand. arkhit. Moscow, 1984.

29. Moizer Filipp. Seismicheskii modernizm. Arkhitektura i domostroenie sovetskogo Tashkenta. Teoriya $i$ istoriya [Seismic modernism. Architecture and house-building of Soviet Tashkent. Theory and history]. Berlin, DOM publishers, 2017, 256 p.

Малиновская Елизавета Григорьевна (Алматы, Казахстан). Кандидат искусствоведения, доцент. Директор картинной галереи «ARK» (050051, Казахстан, Алматы, б/ц «Достар», пр. Достык 240, оф. 107). Эл. почта: eliz.mln@gmail.com.

Elizaveta G. Malinovskaya (Almaty, Kazakhstan ). Candidate of Art History, Associate Professor. Director of Art Gallery "ARK" (240 Dostyk Ave., off. 107, "Dostar" Business Center, Almaty, Kazakhstan, 050051).E-mail: eliz.mln@gmail.com. 